\title{
Pleistocene magnetochronology of early hominin sites at Ceprano and Fontana Ranuccio, Italy
}

\author{
Giovanni Muttoni ${ }^{\mathrm{a}, *}$, Giancarlo Scardia ${ }^{\mathrm{b}}$, Dennis V. Kent ${ }^{\mathrm{c}, \mathrm{d}}$, Carl C. Swisher ${ }^{\mathrm{c}}$, Giorgio Manzi ${ }^{\mathrm{e}}$ \\ a Department of Earth Sciences, University of Milan, via Mangiagalli 34, I-20133 Milan, Italy, \& ALP - Alpine Laboratory of Paleomagnetism, via Madonna dei Boschi 76, \\ I-12016 Peveragno (CN), Italy \\ ${ }^{\mathrm{b}}$ Istituto Nazionale di Geofisica e Vulcanologia, Sezione di Milano-Pavia, via Bassini 15, I-20133 Milano, Italy \\ ${ }^{c}$ Department of Earth and Planetary Sciences, Rutgers University, Piscataway, NJ 08854, USA \\ d Lamont-Doherty Earth Observatory, Palisades, NY 10964, USA \\ e Department of Animal and Human Biology, Università di Roma La Sapienza, Piazzale Aldo Moro 5, 00185 Roma, Italy
}

\section{A R T I C L E I N F O}

\section{Article history:}

Received 17 March 2009

Received in revised form 21 June 2009

Accepted 22 June 2009

Available online 24 July 2009

\section{Keywords:}

Pleistocene

Ceprano

Fontana Ranuccio

magnetostratigraphy

hominins

Italy

\begin{abstract}
A B S T R A C T
Paleomagnetic analyses were conducted on two cores drilled at Ceprano in central Italy where an incomplete hominin cranium was discovered in 1994, as well as on two additional cores from the nearby site of Fontana Ranuccio that yielded hominin remains associated with an Acheulean industry. No evidence for the $0.78 \mathrm{Ma}$ Brunhes-Matuyama boundary was found at Ceprano down to $45 \mathrm{~m}$ below the level that yielded the hominin cranium. The Ceprano lithostratigraphy and the paleomagnetic age constraints are broadly consistent with the stratigraphy of the Liri lacustrine sequence of the Latina Valley, constrained by published $\mathrm{K}-\mathrm{Ar}$ ages between $\sim 0.6$ and $\sim 0.35 \mathrm{Ma}$, and according to an age model with magnetic susceptibility supported by pollen facies data, suggest that the level that yielded the hominin cranium has an age of $\sim 0.45(+0.05,-0.10) \mathrm{Ma}$. Evidence for the Brunhes-Matuyama boundary was found at Fontana Ranuccio about $40 \mathrm{~m}$ below the hominin level, consistent with a K-Ar age of $\sim 0.46$ Ma reported for this level. Hence the Ceprano and Fontana Ranuccio hominin occurrences may be of very similar mid-Brunhes age.
\end{abstract}

(c) 2009 Elsevier B.V. All rights reserved.

\section{Introduction}

Direct evidence of early hominin occupation in Italy includes an incomplete hominin cranium discovered in 1994 along a roadcut near Ceprano, southeast of Rome (Ascenzi et al., 1996), as well as hominin teeth possibly attributed to Homo erectus associated with a Mode II (Acheulean) tool industry at the nearby site of Fontana Ranuccio (e.g., Segre and Ascenzi, 1984; Segre, 2004; Segre Naldini et al., 2009). The Ceprano cranium has been variably ascribed to a new species $H$. cepranensis (Mallegni et al., 2003), a late variant of $H$. erectus (Ascenzi et al., 1996, 2000) H. erectus sensu latu (Clarke, 2000), a possible adult representative of $H$. antecessor (Manzi et al., 2001; Manzi, 2004; Bruner and Manzi, 2005), or to an ancestral morphotype of the $H$. heidelbergensis/rhodesiensis hypodigm (Bruner and Manzi, 2007). Despite its taxonomic uncertainty, the Ceprano cranium is commonly regarded as representative of one of the oldest hominins that populated Europe (Italy and Spain) at about $1 \mathrm{Ma}$ (Dennell, 2008) and that possibly represented the link between early Homo and $H$. heidelbergensis, the main type of hominin evidenced in Europe in the Middle Pleistocene (Manzi, 2004; Bruner and Manzi, 2007; Dennell, 2008).

\footnotetext{
* Corresponding author.

E-mail address: giovanni.muttoni1@unimi.it (G. Muttoni).
}

Based on stratigraphic and geologic arguments and built on a complex correlation framework between discontinuous continental sections, the Ceprano cranium was considered by several authors (e.g., Ascenzi et al., 1996; Ascenzi and Segre, 1997; Ascenzi et al., 2000; Manzi, 2004) to be older than the oldest Latian volcanic activity dated in the region to $\sim 0.7 \mathrm{Ma}$ (Carrara et al., 1995; Fornaseri, 1985; Peccerillo, 2005) and therefore close to the Brunhes-Matuyama polarity chron boundary $(0.78 \mathrm{Ma}$; geomagnetic polarity time scale incorporating astronomical dating as summarized by Berggren et al., 1995 , is used throughout), although no paleomagnetic data were provided in support of this interpretation.

Preliminary paleomagnetic analyses (DVK) on 8 samples taken (CCS) from the $\sim 1 \mathrm{~m}$-thick roadcut section that yielded the hominin cranium gave unstable directions save for three samples characterized by a normal magnetic polarity component (see below), but the section was too short to confirm reliability of the magnetic results or determine any correlation with the geomagnetic polarity time scale. To address these issues, we organized the drilling of two long cores at Ceprano, where expanded sections are not exposed, with the aim to establish a magnetic polarity stratigraphy and therefore provide constraints on the age of the Ceprano hominin fossil. Here we report the paleomagnetic data used to construct age models of sedimentation for the Ceprano 1 and Ceprano 2 cores that bring a revision of the age of the Ceprano cranium. By exploiting the opportunity provided 
by two additional cores taken in 2004 by A.G. Segre at the early hominin site of Fontana Ranuccio, we also searched for the BrunhesMatuyama boundary at this locality.

\section{Geological setting}

The Ceprano and Fontana Ranuccio sites are located in the Latina Valley about $90 \mathrm{~km}$ and $50 \mathrm{~km}$ southeast of Rome, respectively (Fig. 1A). The Latina Valley consists of several extensional tectonic basins, including the Ceprano basin (hosting the Ceprano site) and the Anagni basin (hosting the Fontana Ranuccio site). These basins, bounded by horsts of Mesozoic to Miocene limestones (Segre and Ascenzi, 1984; Carrara et al., 1995; Ascenzi et al., 1996; Segre, 2004), developed mainly between the Late Pliocene and the earlier part of the Middle Pleistocene (Carrara et al., 1995; Galadini and Messina, 2004) and were characterized by regional volcanic activity [Alban Hills (Latian) and Ernici-
Roccamonfina magmatic provinces] since about $0.6 \mathrm{Ma}$ (e.g., Giannetti, 2001; Peccerillo, 2005; Rouchon et al., 2008) (Fig. 1A).

The Anagni basin, where the Fontana Ranuccio site is located, is bounded to the southeast by the Sgurgola-Ferentino bedrock ridge that possibly acted as a dam for lacustrine and fluvial sedimentation during the Early Pleistocene (Alberti et al., 1975) (Fig. 1B). These lacustrine-alluvial sediments, which we encountered in our drillings at Fontana Ranuccio (units 2-3; see below), were covered by Middle Pleistocene pyroclastics, dated at Fontana Ranuccio between $0.528 \mathrm{Ma}$ and $0.487 \mathrm{Ma}$ (K-Ar, Biddittu et al., 1979; see below) and attributed to the Alban Hills magmatic province ( 0.6-0.02 Ma; Peccerillo, 2005; Fig. 1A,B), and by travertine (Segre and Ascenzi, 1984).

The Ceprano basin is comprised broadly between the Ceprano site and the Roccamonfina volcanic complex (Fig. 1A,C) and was the locus of extensive lacustrine sedimentation during the Middle Pleistocene the Liri lacustrine sequence (Devoto, 1965; Carrara et al., 1995) -
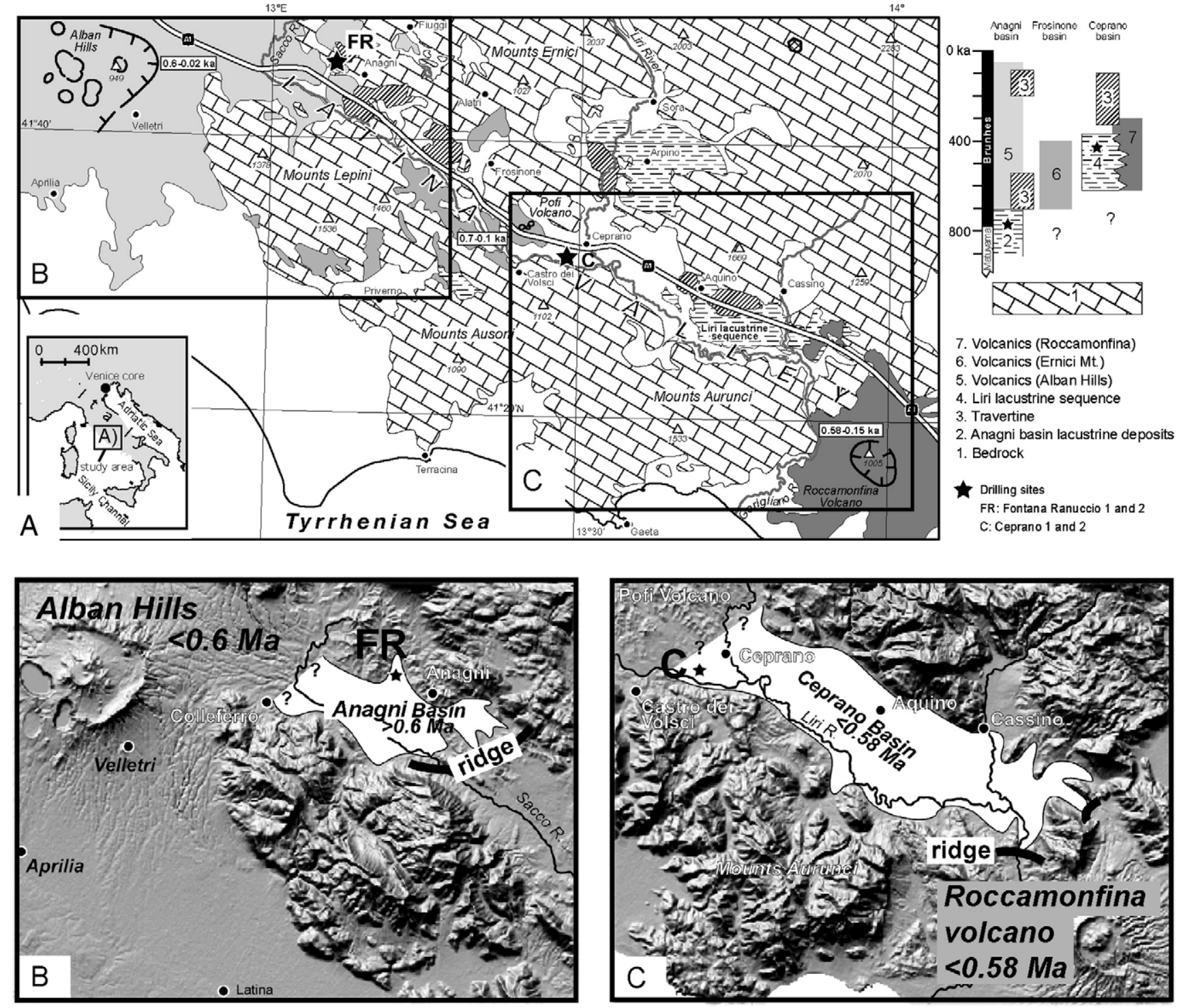

Fig. 1. (A) Simplified geologic map of the Latina Valley (adapted from Segre, 2004) with indication of the drill sites (C = Ceprano 1 and Ceprano 2; FR = Fontana Ranuccio 1 and Fontana Ranuccio 2). The stratigraphic setting of lacustrine deposition in the Latina Valley during the Pleistocene is also indicated in the right panel. (B) Digital elevation model of the Alban Hills-Anagni basin area; the white shaded area represents the inferred distribution of the $>\sim 0.6$ Ma lacustrine deposition in the Anagni basin (FR $=$ Fontana Ranuccio 1 and Fontana Ranuccio 2). (C) Digital elevation model of the Roccamonfina volcano-Ceprano basin area; the white shaded area represents the inferred distribution of the $<\sim 0.6$ Ma lacustrine deposition in the Ceprano basin ( $\mathrm{C}=$ Ceprano 1 and Ceprano 2$)$. 
possibly triggered by the damming of the southeastern outlet of the Latina Valley (Devoto, 1965; Carrara et al., 1995) by the Roccamonfina volcanic complex, active between $\sim 0.6$ and $\sim 0.15$ Ma (De Rita and Giordano, 1996; Giannetti, 2001; Giordano et al., 2006; Rouchon et al., 2008) (Fig. 1C). Hominin footsteps were recently found in an ash deposit of the Roccamonfina volcanic complex (Mietto et al., 2003) and dated by ${ }^{40} \mathrm{Ar} /{ }^{39} \mathrm{Ar}$ on single leucite crystals to $0.345 \pm 0.006 \mathrm{Ma}$ (Scaillet et al., 2008). The Liri lacustrine sequence, as recognized in the Ceprano site area, consists of three main lithostratigraphic units with a total maximum thickness of $\sim 100 \mathrm{~m}$ in the type-area (Devoto, 1965). At the base of the sequence is a white calcareous mud with interbedded black graded tephras ("lower lacustrine mud" of Devoto, 1965; lacustrine basinal facies), passing upward to cross-bedded yellow sand, gravel and calcareous mud ("typical lacustrine facies" of Devoto, 1965; fluvial and nearshore lacustrine facies), and capped by lacustrine travertine and calcareous mud, locally rich in organic matter ("late lacustrine facies" of Devoto, 1965; nearshore lacustrine and/or marsh facies).

In our drilling at Ceprano, we encountered a sequence of lithological units (1-4; see below) that are interpreted as representing, from top to bottom, the "late lacustrine facies" (unit 1), the "typical lacustrine facies" (unit 2), and the "lower lacustrine mud" (unit 4) of the Liri lacustrine sequence of Devoto (1965). The Liri lacustrine sequence is constrained by $\mathrm{K}-\mathrm{Ar}$ ages on fallout (nonreworked) tephra layers of $0.570 \pm 0.011 \mathrm{Ma}$ and $0.583 \pm 0.011 \mathrm{Ma}$ (sample BIF 124 on leucite) from the "lower lacustrine mud" and $0.354 \pm 0.007 \mathrm{Ma}$ and $0.359 \pm 0.007 \mathrm{Ma}$ (sample BIF171 on K-feld- spar) from the "late lacustrine facies" (Carrara et al., 1995; International Conventional Constants used for age calculation from Steiger and Jager, 1977). Although we could not find conclusive evidence of (laterally discontinuous?) tephra layers in the Ceprano cores (i.e., in unit $1 \approx$ "late lacustrine facies" and in unit $4 \approx$ "lower lacustrine mud"), the available radiometric age constraints (Carrara et al., 1995) bracket the Liri lacustrine deposition at Ceprano in a time window broadly comprised between $\sim 0.6$ and $\sim 0.35$ Ma.

In summary, the Anagni basin, where the Fontana Ranuccio site is located, hosted lacustrine sedimentation before, and during the early stages of, the Alban Hills volcanic activity, i.e. roughly before 0.5$0.6 \mathrm{Ma}$, whilst the Ceprano basin, where the Ceprano site is located, hosted lacustrine sedimentation during the Roccamonfina volcanic activity broadly between $\sim 0.6$ and $\sim 0.35 \mathrm{Ma}$. Therefore, we might expect to find the Brunhes-Matuyama polarity reversal in the lacustrine deposits of Fontana Ranuccio and exclusively normal polarity of the Brunhes chron in the lacustrine deposits of Ceprano.

\section{Lithostratigraphy of cores}

Drilling at Ceprano 1 was carried out a few meters to the southeast of the roadcut that yielded the hominin cranium (Fig. 2). The hominin stratigraphic level was traced laterally into the core stratigraphy at about $1.5 \mathrm{~m}$ below the ground surface; drilling further penetrated the underlying sediments to a total depth of $48 \mathrm{~m}$ with a total core recovery of $97 \%$ (drilling details in Online Table 1). Ceprano 1 is characterized by four main lithologic units (Fig. 3). The upper part of the core (unit 1;0.3-

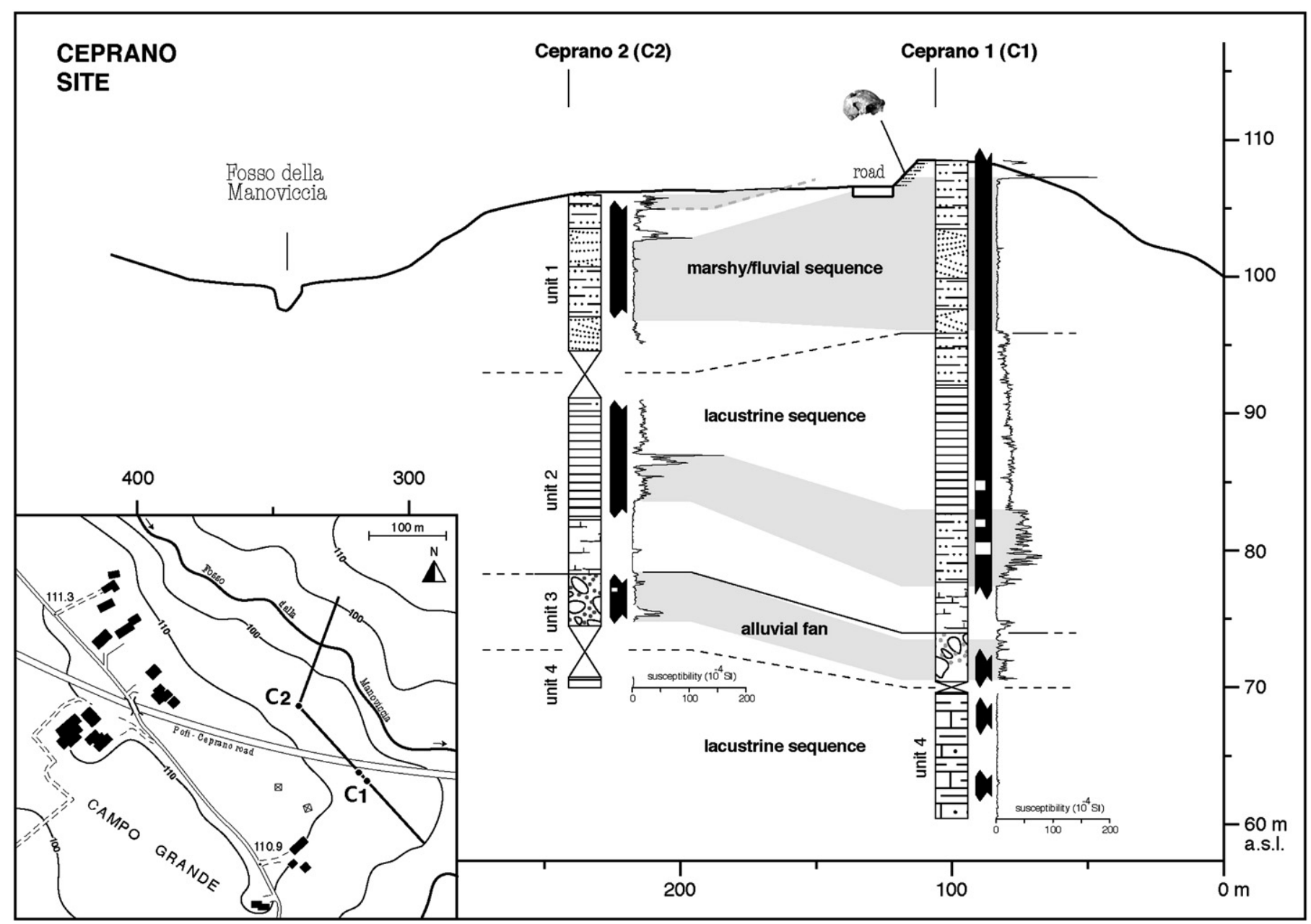

Fig. 2. Physical correlation of the Ceprano 1 and Ceprano 2 cores placed in a detailed topographic context. Lithology and suceptibility data show the lateral consistency of the predominantly normal polarity interval (positive ChRM inclinations) therein retrieved (black is normal polarity, white is dubious reverse polarity; see discussion). The discovery site and stratigraphic position of the Ceprano cranium are indicated. 
$12.6 \mathrm{~m}$ ) consists of fine to medium-grained, well-sorted sands, possibly pertaining to meandering fluvial channels, interbedded with massive packages of oxidized silty clays with carbonate nodules, and brown organic-rich clays, ascribable to floodplain and marsh environments, respectively (this unit should correspond to the "late lacustrine facies" of Devoto, 1965 with associated K-Ar ages of $\sim 0.35$ Ma of Carrara et al., 1995; see above). Below is a lacustrine sequence (unit 2; 12.6-34.5 m) starting with coarse gyttja and low-energy alluvial deposits (12.6$16.4 \mathrm{~m}$ ) underlain by laminated mud and normal-graded sands, interpreted as turbidites (lacustrine basinal facies; 16.4-30.8 m), and carbonate tufa with plant macroremains (lacustrine nearshore facies; 30.8-34.5 m); unit 2 should correspond to the "typical lacustrine facies" of Devoto (1965). From 34.5 to $38.0 \mathrm{~m}$ (unit 3), the core comprises sandy to clayey gravels with poorly rounded pebbles, possibly pertaining to an alluvial fan deposit. Finally, from 38.8 to $48.0 \mathrm{~m}$ (unit 4 ) the core consists of consolidated laminated marls interpreted as a lacustrine deposit, which should correspond to the "lower lacustrine mud" of Devoto (1965) with associated K-Ar ages of $\sim 0.6$ Ma (Carrara et al., 1995; see

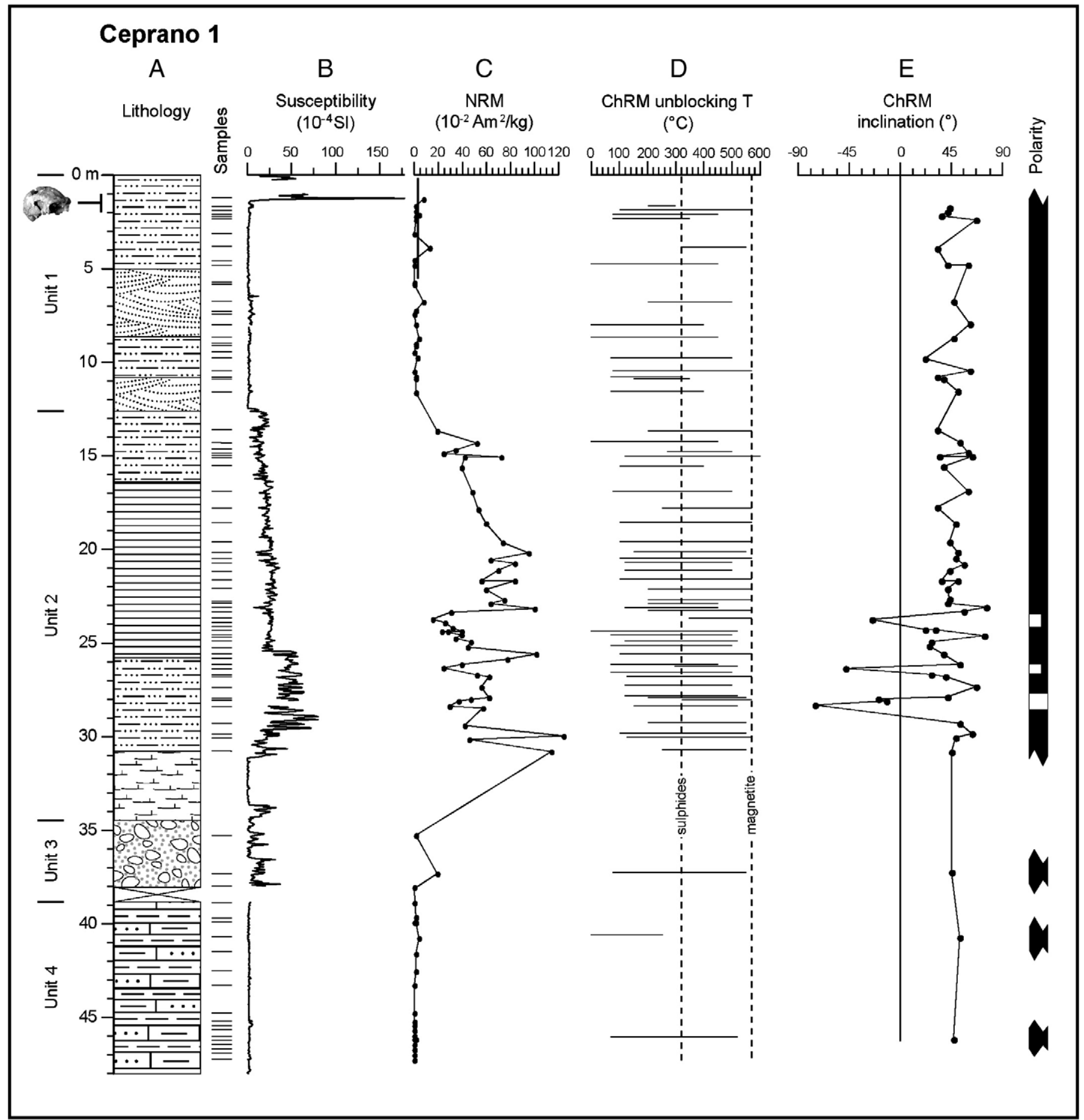

Fig. 3. Stratigraphic synthesis of the Ceprano 1 core with (A) lithology and stratigraphic position of paleomagnetic samples taken for analysis, (B) magnetic susceptibility, (C) weighted NRM intensity, (D) unblocking temperature spectra of the ChRM component, and (E) inclination values of the ChRM component used for polarity interpretation (black is normal polarity, white is dubious reverse polarity; see discussion). The stratigraphic position of the Ceprano cranium is indicated at the top of the Ceprano 1 core. 
above). According to a preliminary palynological study, the Ceprano 1 core from meter levels 14 to 24 within lacustrine unit 2 yielded forest pollen associations of temperate climatic conditions (with, among others, Carpinus, Ulmus, deciduous Quercus, Alnus, Corylus, and Hedera) compatible with an interglacial period (Margari et al., 2008).

Drilling at Ceprano 2 (details in Online Table 1 ) penetrated $36 \mathrm{~m}$ of sediments about $140 \mathrm{~m}$ northwest of Ceprano 1 (Fig. 2) to test the lateral continuity of the sedimentary succession. The Ceprano 2 core displays a four-fold lithostratigraphic subdivision (interrupted by non-recovery gaps) broadly similar to that observed at Ceprano 1 (Fig. 4) and consisting of alluvial deposits (unit 1; 0-11.3 m), lacustrine deposits (unit 2; 14.9-27.8 m), poorly recovered sandy to clayey gravels (unit 3; 27.8-31.5 m), and laminated marls (unit 4; 35.3-36.0 m).

Fontana Ranuccio 1 and Fontana Ranuccio 2 were drilled respectively $\sim 50 \mathrm{~m}$ to the east and $\sim 100 \mathrm{~m}$ to the west of the site that yielded hominin teeth and Acheulean tool assemblages (Fig. 5). The archaeological layer at this site, dated by $\mathrm{K}-\mathrm{Ar}$ on leucites to $0.458 \pm$ $0.006 \mathrm{Ma}$ (Biddittu et al., 1979; Segre and Ascenzi, 1984), is interbedded in a succession of weathered volcanoclastic and volcanic layers, outcropping along quarry terraces \#2 and \#3, capped by tuff (locally known as tufo litoide) and resting above a pyroclastic deposit (locally known as pozzolana) attributed to the Latian-Alban volcanic activity (Segre Naldini et al., 2009) (Fig. 5). This pyroclastic deposit is dated between $0.487 \pm 0.008 \mathrm{Ma}$ (top) and $0.528 \pm 0.006 \mathrm{Ma}$ (base) by $\mathrm{K}-\mathrm{Ar}$ on leucites from samples from quarry outcrops (Biddittu et al., 1979), thus providing a maximum age consistent with the direct date on the archaeological level (Fig. 5). In detail, Fontana Ranuccio 1 (Fig. 6, upper panel; Online Table 1) consists, from top to bottom, of $\sim 1 \mathrm{~m}$ of deposits reworked by quarry activity followed down-section by the pyroclastic deposit

\section{Ceprano 2}

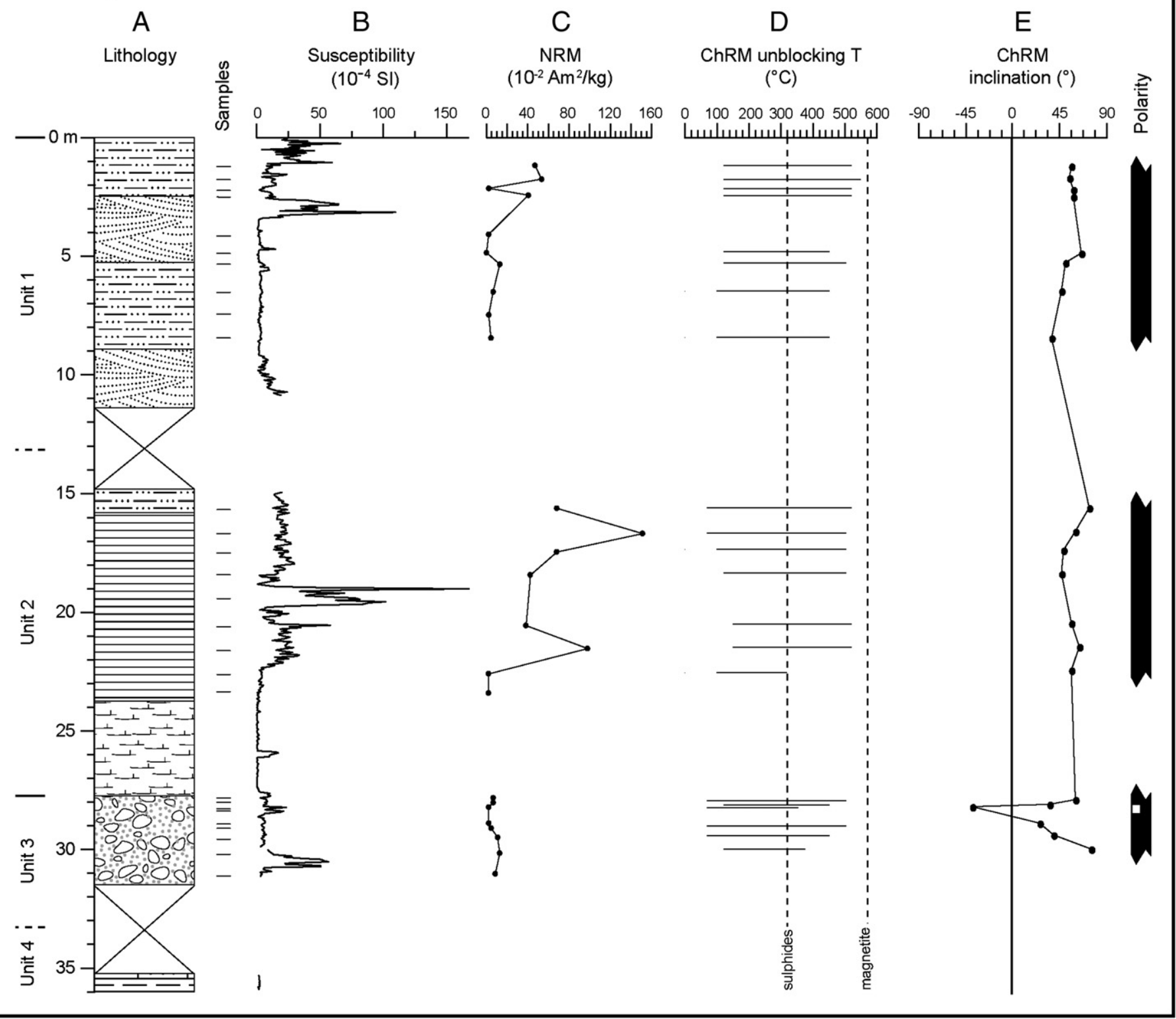

Fig. 4. Stratigraphic synthesis of the Ceprano 2 core with (A) lithology and stratigraphic position of paleomagnetic samples taken for analysis, (B) magnetic susceptibility, (C) weighted NRM intensity, (D) unblocking temperature spectra of the ChRM component, and (E) inclination values of the ChRM component used for polarity interpretation (black is normal polarity, white is dubious reverse polarity; see discussion). 


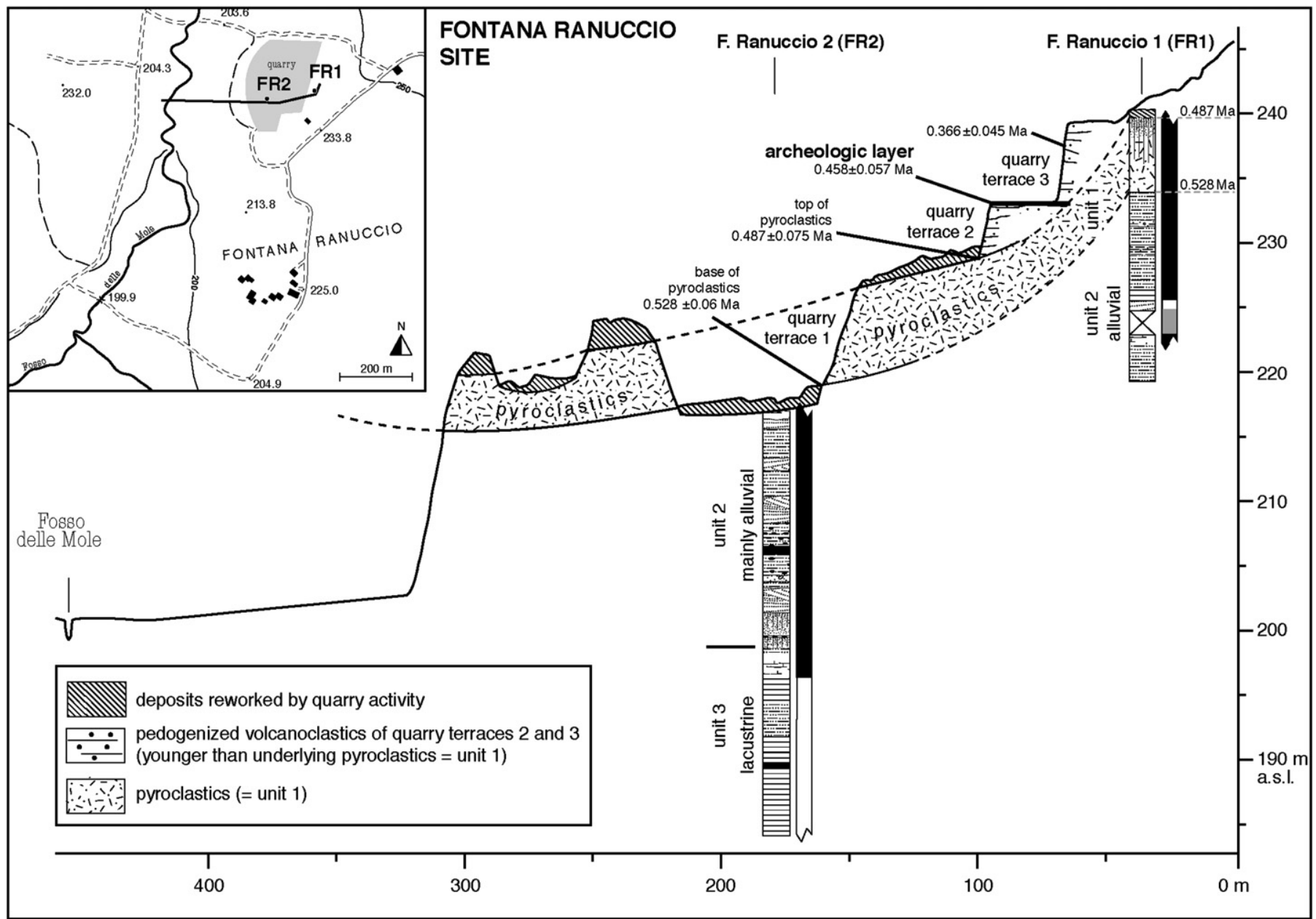

Fig. 5. Physical correlation of the Fontana Ranuccio 1 and Fontana Ranuccio 2 cores placed in detailed topographic and geologic context (modified from Segre Naldini et al., 2009) (black is normal polarity, white is reverse polarity). The stratigraphic position of the Acheulean industry with hominin teeth and the associated K-Ar ages (see text for references) are indicated.

( 1-6.4 m, unit 1), the top of which should fall, according to field observations, close to the core top (Figs. 5 and 6). Pyroclastic unit 1 is underlain from $6.4 \mathrm{~m}$ to the core bottom at $21.0 \mathrm{~m}$ by a composite package (unit 2) of brown to red silty clays with plant macroremains interbedded with gravels and volcanoclastic sands attributed to marsh and floodplain settings.

Fontana Ranuccio 2 was drilled for a total of $33 \mathrm{~m}$ from just below the base of the same pyroclastic deposit of unit 1 at Fontana Ranuccio 1 down into the underlying alluvial to lacustrine sediments (Fig. 5). Inspection of Fig. 5 reveals that the lateral variation in thickness and elevation of the pyroclastic deposit observed between Fontana Ranuccio 1 and Fontana Ranuccio 2 is probably due to emplacement on a pre-existing, irregular topography. The stratigraphy at Fontana Ranuccio 2 (Fig. 6, lower panel; Online Table 1) starts with unit 2 (0.9$19.3 \mathrm{~m}$ ) composed of a complex assemblage of laminated mud with freshwater mollusks interbedded with volcanoclastic sands (0.9$4.5 \mathrm{~m}$ ), organic-rich clayey layers interbedded with volcanoclastic sands (4.5-16.6 m), and oxidized silty clays (16.6-19.3 m), altogether attributed to marsh to floodplain (alluvial) settings. Below is unit 3 (19.3-33.0 m) composed of calcareous muds (19.3-20.7 m) passing downward to laminated mud with interbedded fine-grained, graded sands and organic-rich layers (20.7-33.0 m) attributed to lacustrine settings.

\section{Paleomagnetism of cores}

Paleomagnetic analyses were conducted at the ALP - Alpine Laboratory of Paleomagnetism (Peveragno, Italy). Paleomagnetic samples were extracted from the most cohesive fine-grained intervals at Ceprano 1 (90 samples/103 $8 \mathrm{cc}$ cubic specimens for analysis), Ceprano 2 (28 samples/29 specimens), Fontana Ranuccio 1 (25 samples/21 specimens), and Fontana Ranuccio 2 (32 samples/32 specimens). These samples could not be oriented with respect to geographic north as the cores were not oriented azimuthally during drilling. Magnetic susceptibility profiles for Ceprano 1 and Ceprano 2 were measured every $5 \mathrm{~cm}$ with a Bartington MS2E1 contact sensor. Magnetic susceptibility was also measured on all samples with a Kappabridge KLY-3 and, in addition, the anisotropy of magnetic susceptibility was measured on 34 samples from Ceprano 1 with the same instrument. A representative suite of samples from Ceprano and Fontana Ranuccio was subjected to rock-magnetic analysis using isothermal remanent magnetization (IRM) backfield acquisition curves (up to $2.5 \mathrm{~T}$ ) and thermal demagnetization of a three component IRM (Lowrie, 1990) along sample orthogonal axes in $2.5 \mathrm{~T}$ (high), $0.4 \mathrm{~T}$ (medium), and $0.12 \mathrm{~T}$ (low) fields. All remanence measurements were made on a 2G-Enterprises DC SQUID cryogenic magnetometer located in a magnetically shielded room with ambient

Fig. 6. Stratigraphic synthesis of the Fontana Ranuccio 1 and Fontana Ranuccio 2 cores with (A) lithology and stratigraphic position of paleomagnetic samples taken for analysis, (B) magnetic susceptibility, (C) weighted NRM intensity, (D) unblocking temperature spectra of the ChRM component, and (E) inclination values of the ChRM component used for polarity interpretation (black is normal polarity, white reverse polarity). 


\section{Fontana Ranuccio 1}

A

Lithology

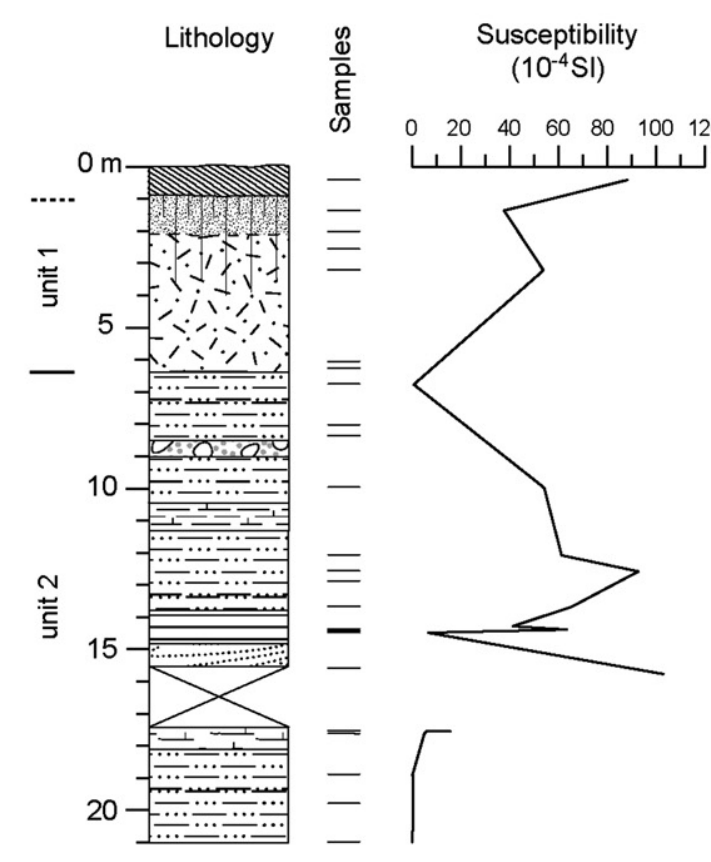

C

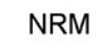

$\left(\mathrm{Am}^{2} / \mathrm{kg}\right)$
D

ChRM unblocking T

$\left({ }^{\circ} \mathrm{C}\right)$

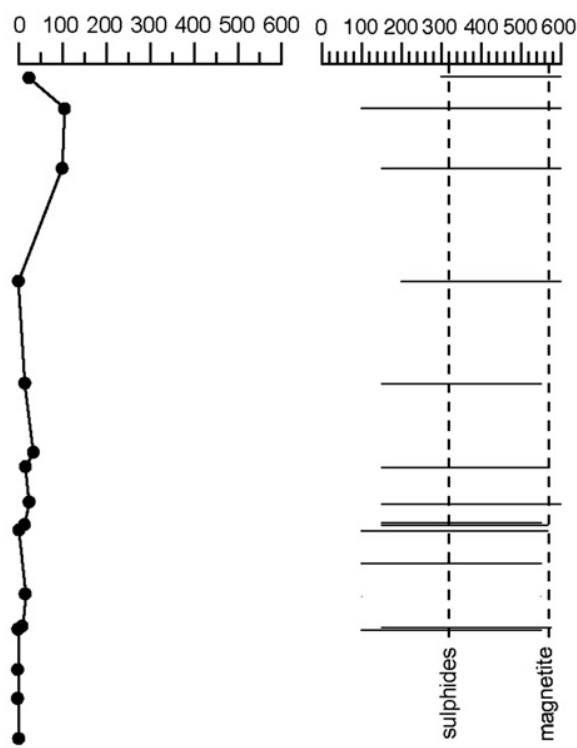

E

ChRM inclination

$\left({ }^{\circ}\right)$

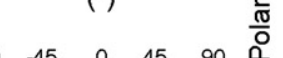

$\begin{array}{llllll}-45 & 0 & 45 & 90 & 0\end{array}$

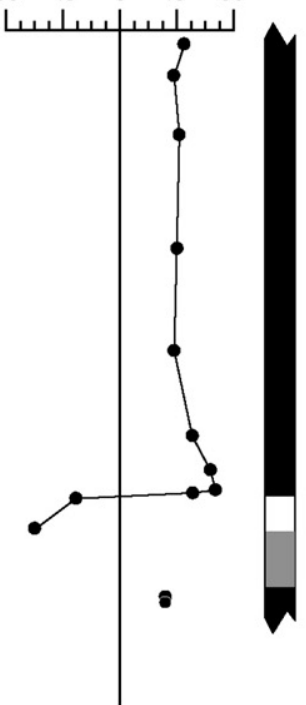

\section{Fontana Ranuccio 2}

$\stackrel{\sqrt{2}}{\frac{2}{2}}$

S $0 \mathrm{~m}$

$$
-\quad 5
$$

늗ㄴ.?

늗

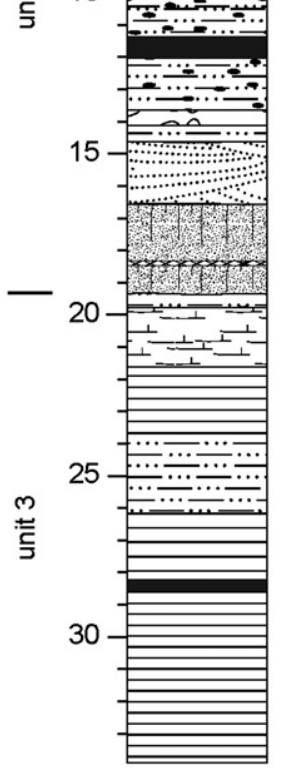

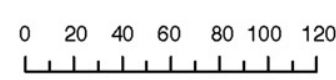
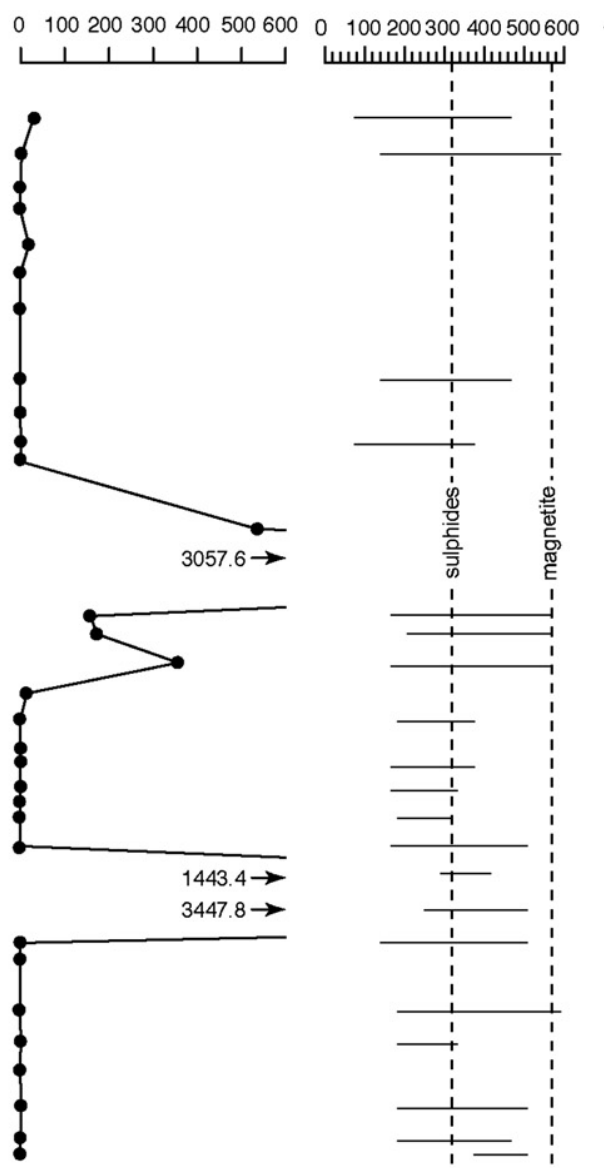

$\begin{array}{lllll}-90 & -45 & 0 & 45 & 90\end{array}$ لسلسلسلسلسلس

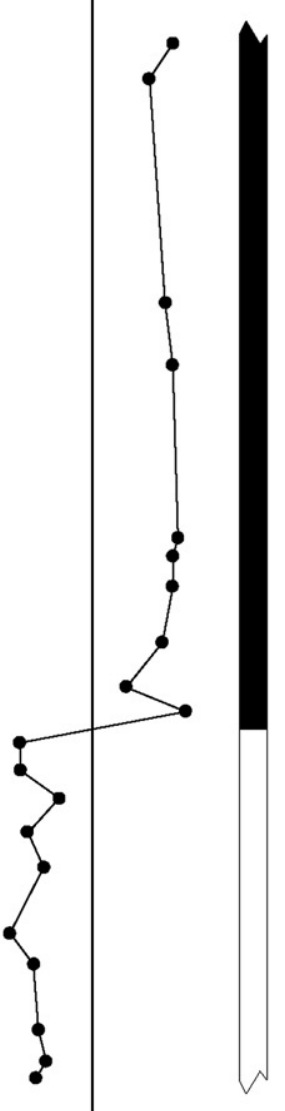




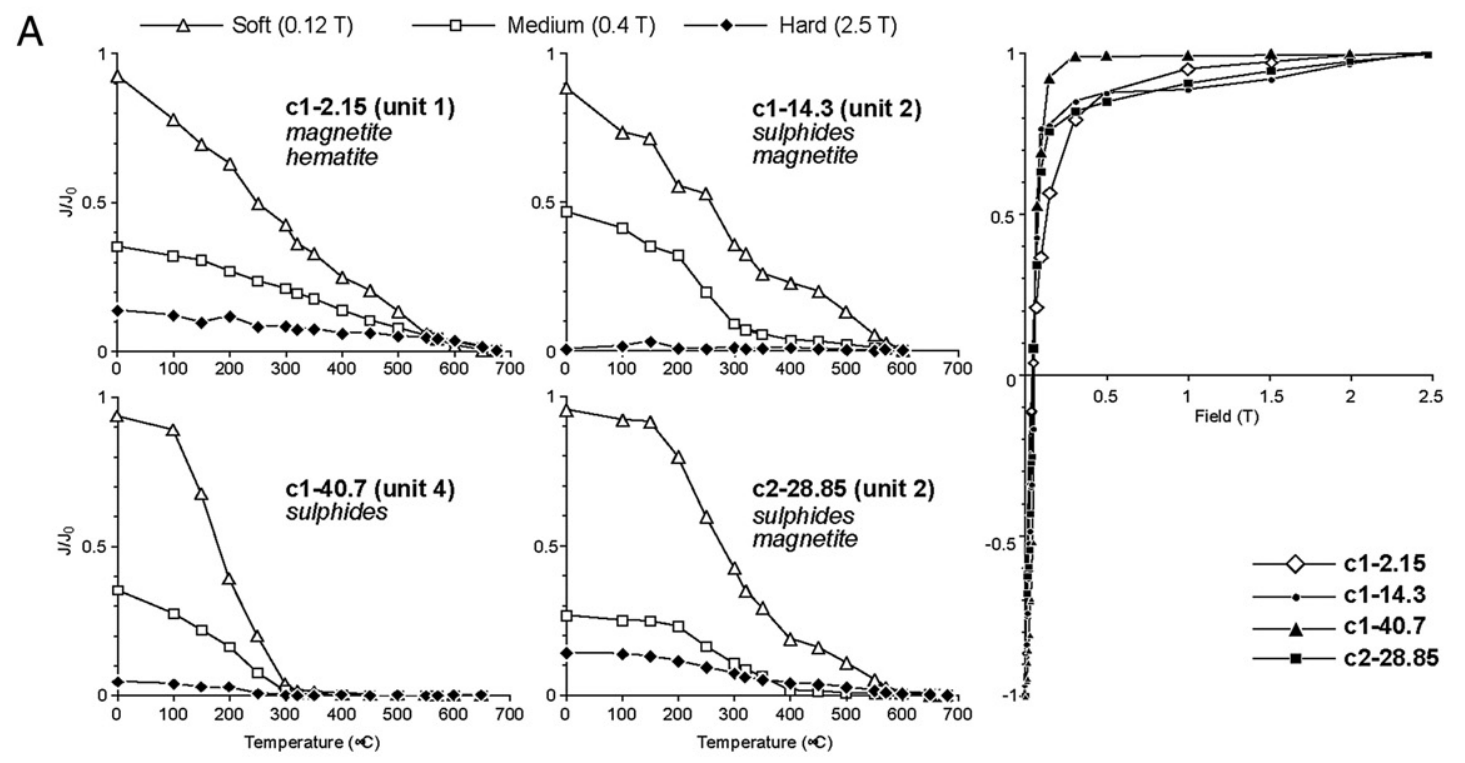

B

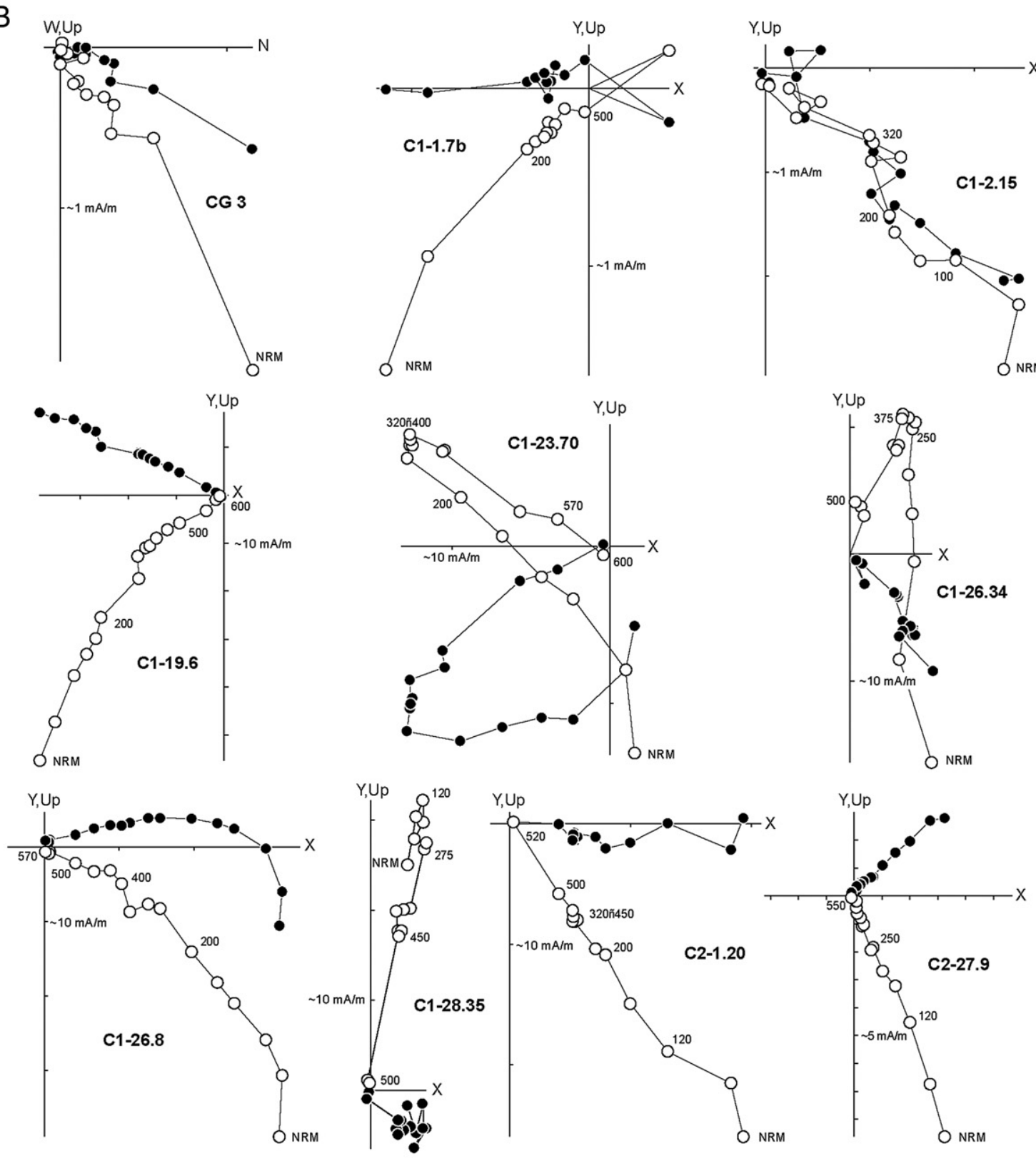


fields reduced to $\sim 300 \mathrm{nT}$. After rock-magnetic screening, the remainder of the samples were thermally demagnetized up to a (rare) maximum of $600{ }^{\circ} \mathrm{C}$ adopting $50{ }^{\circ} \mathrm{C}$ steps or $25-10{ }^{\circ} \mathrm{C}$ steps close to critical unblocking temperatures, and the component structure of the natural remanent magnetization (NRM) was monitored by means of vector endpoint demagnetization diagrams (Zijderveld, 1967). Magnetic components were calculated by standard least-square analysis (Kirschvink, 1980) on linear portions of the demagnetization paths.

\subsection{Ceprano}

Ceprano 1 (Fig. 3A) and Ceprano 2 (Fig. 4A) show similar magnetic susceptibility and NRM intensity patterns characterized by high values in volcanoclastic-rich intervals, i.e. toward the top of unit 1 and in units $2-3$, and lower values in the mid-lower part of unit 1 and in unit 4 (Figs. 3B,C and 4B,C). The anisotropy of magnetic susceptibility shows that samples from Ceprano 1 have magnetic fabrics generally more foliated $($ mean foliation $=1.019$; standard deviation $\sigma=0.018$ ) than lineated (mean lineation $=1.010 ; \sigma=0.015$ ), and consequently their magnetic ellipsoids are preferentially oblate [shape parameter (Hrouda, 2002) on average $>0$ ]. In any case, the anisotropy degree of these samples is low (mean anisotropy $=1.029 ; \sigma=0.031$ ) and foliation poles (minimum susceptibility axes) are subvertical, reflecting subhorizontal to very shallow bedding planes. The IRM acquisition curves and the thermal decay of a three component IRM show the presence essentially of a low coercivity component with maximum unblocking temperatures around $\sim 570^{\circ} \mathrm{C}$ interpreted as magnetite, co-existing with a higher coercivity component with blocking temperatures around $\sim 300^{\circ} \mathrm{C}$ and interpreted as a sulphide phase (Fig. 7A).

Orthogonal projections of thermal demagnetization data of the 8 oriented samples originally taken from the outcrop section that yielded the hominin cranium show the presence of unstable paleomagnetic directions save for three samples characterized by a characteristic (ChRM) component direction trending to the origin of the demagnetization axes. This ChRM is oriented north and down (i.e., with positive inclination) and was acquired during a normal magnetic polarity interval (e.g., sample cg3, Fig. 7B). Orthogonal projections of thermal demagnetization data of the samples extracted from the cores indicate the existence of a ChRM component trending to the origin of the demagnetization axes (Fig. 7B) in 57\% of the Ceprano 1 samples $(N=62)$ up to maximum unblocking temperatures of $\sim 575{ }^{\circ} \mathrm{C}$ (Fig. 3D) and in $72 \%$ of the Ceprano 2 samples $(N=21)$ up to maximum unblocking temperatures of $\sim 525-550{ }^{\circ} \mathrm{C}$ (Fig. 4D). The relatively low percentage of samples yielding a ChRM at Ceprano 1 is essentially due to the unstable nature of the NRM in samples from unit 4 (38.8-48.0 m). The declination values of the ChRM components are scattered because the cores were not oriented azimuthally during drilling. The inclination values are instead consistently positive (down-pointing) at both Ceprano 1 (e.g., samples c1-1.7b, c1-2.15, c1-19.6, c1-26.8 in Fig. 7B) and Ceprano 2 (e.g., samples c2-1.20 and c2-27.9; Fig. 7B). Rare negative (up-pointing) inclination components, isolated at high temperatures usually after removal of low temperature components of positive inclination, characterize five samples from Ceprano 1 and one sample from Ceprano 2 (e.g., samples c1-23.7, c1-26.34, and c1-28.35; Fig. 7B).

Inclination-only statistics of McFadden and Reid (1982) on the ChRM for Ceprano 1 and Ceprano 2 yielded an overall mean inclination of $47.5^{\circ} \pm 4.0^{\circ}(N=83 ; k=15.5)$. This mean inclination is somewhat shallower than the geocentric axial dipole (GAD) inclination of $\sim 60^{\circ}$ for the core-site latitude, most likely because of depositional inclination error or compaction of the sediments (e.g., Tauxe, 2005).

At Ceprano 1, downward (positive) ChRM inclinations dominate the section from top to bottom, interrupted only by the five samples with upward (negative) ChRM inclinations discussed above, which define three thin intervals (one with three samples) within the volcanoclastic-rich unit 2 in the $\sim 24-30 \mathrm{~m}$ interval (Fig. 3E). The core from $\sim 31 \mathrm{~m}$ to the base $(48 \mathrm{~m}$ ) was characterized by unstable NRM behavior during thermal demagnetization and yielded useful data from only three samples, all with positive ChRM inclinations (Fig. 3E). Ceprano 2 displays positive ChRM inclinations from core top to bottom except for the single sample with negative ChRM inclination found in the sandy gravels of unit 3 (Fig. 4E).

The detailed susceptibility logs bearing distinctive peaks (e.g., within unit 2) and the main lithologic subdivisions allow accurate correlation of the nearby Ceprano 1 and Ceprano 2 cores, thus confirming that the interval of predominantly positive ChRM inclinations therein contained is laterally persistent and continuous (Fig. 2). The susceptibility correlation reveals that Ceprano 2 fails to reproduce the three thin intervals with negative ChRM inclinations observed within unit 2 at Ceprano 1, whereas Ceprano 1 fails to reproduce the (single) negative inclination found at Ceprano 2 within unit 3. This may be because of relative differences in sampling density, or also because these intervals may represent spurious artifacts related to, for example, complex sedimentary processes within the volcanoclasticrich interval of unit 2 or the sandy gravels of unit 3.

In conclusion, we interpret the positive ChRM inclinations recorded at both cores as representing normal geomagnetic polarity, whereas we maintain caution on the interpretation of the sparse negative inclinations therein embedded as representing reverse polarity excursions of the geomagnetic field. The regional context and the core lithostratigraphy allow us to interpret the Ceprano normal polarity magnetozone as pertaining to the Brunhes Chron (C1n).

\subsection{Fontana Ranuccio}

Fontana Ranuccio 1 and 2 (Fig. 6A) display magnetic susceptibility and NRM intensity patterns in units 1 to 3 characterized in general by high values associated with volcanoclastic-rich sandy intervals and lower values associated with clayey intervals (Fig. 6B,C). The IRM acquisition curves and the thermal decay of a three component IRM show the presence of a low coercivity component with maximum unblocking temperatures around $\sim 570^{\circ} \mathrm{C}$ interpreted as magnetite, co-existing with subsidiary higher coercivity components with blocking temperatures around $\sim 300{ }^{\circ} \mathrm{C}$ and $\sim 680^{\circ} \mathrm{C}$ interpreted as a sulphide phase and hematite, respectively (Fig. $8 \mathrm{~A}$ ).

Orthogonal projections of demagnetization data from both cores typically show the removal of viscous magnetic components up to a demagnetization temperature of $\sim 150{ }^{\circ} \mathrm{C}$ to reveal a ChRM component with demagnetization trajectories that converge to the origin by $570-$ $600{ }^{\circ} \mathrm{C}$ (Fig. 8B); these maximum unblocking temperatures point to the presence of magnetite as the dominant carrier of the remanence (Fig. 6D). The ChRM component was isolated in $65 \%$ of the Fontana Ranuccio 1 samples $(N=13)$ and in $62 \%$ of the Fontana Ranuccio 2 samples $(N=20)$. The ChRM inclinations are predominantly downpointing (positive) at Fontana Ranuccio 1 (e.g., samples s1-1.40, s16.80, s1-17.65 in Fig. 8B) except for two samples (s1-14.50 and s1-

Fig. 7. (A) Rock-magnetic analyses on Ceprano 1 (c1) and Ceprano 2 (c2) samples using isothermal remanent magnetization (IRM) backfield acquisition curves (up to 2.5 T) and thermal decay of a three component IRM (Lowrie, 1990) acquired along samples perpendicular axes in $2.5 \mathrm{~T}$ (high), $0.4 \mathrm{~T}$ (medium), and $0.12 \mathrm{~T}$ (low) fields. (B) Examples of Zijderveld (1967) demagnetization diagrams of Ceprano 1 (c1) and Ceprano 2 (c2) samples. Open (closed) symbols are projections onto the vertical (horizontal) plane. Horizontal projections have arbitrary azimuths, as cores were not oriented with respect to the geographic north (save for oriented sample cg3 from the outcrop section). Samples are identified by the core code ( $\mathrm{c} 1, \mathrm{c} 2)$ and stratigraphic depth in meters from the top (save for sample cg3 from the outcrop section). 


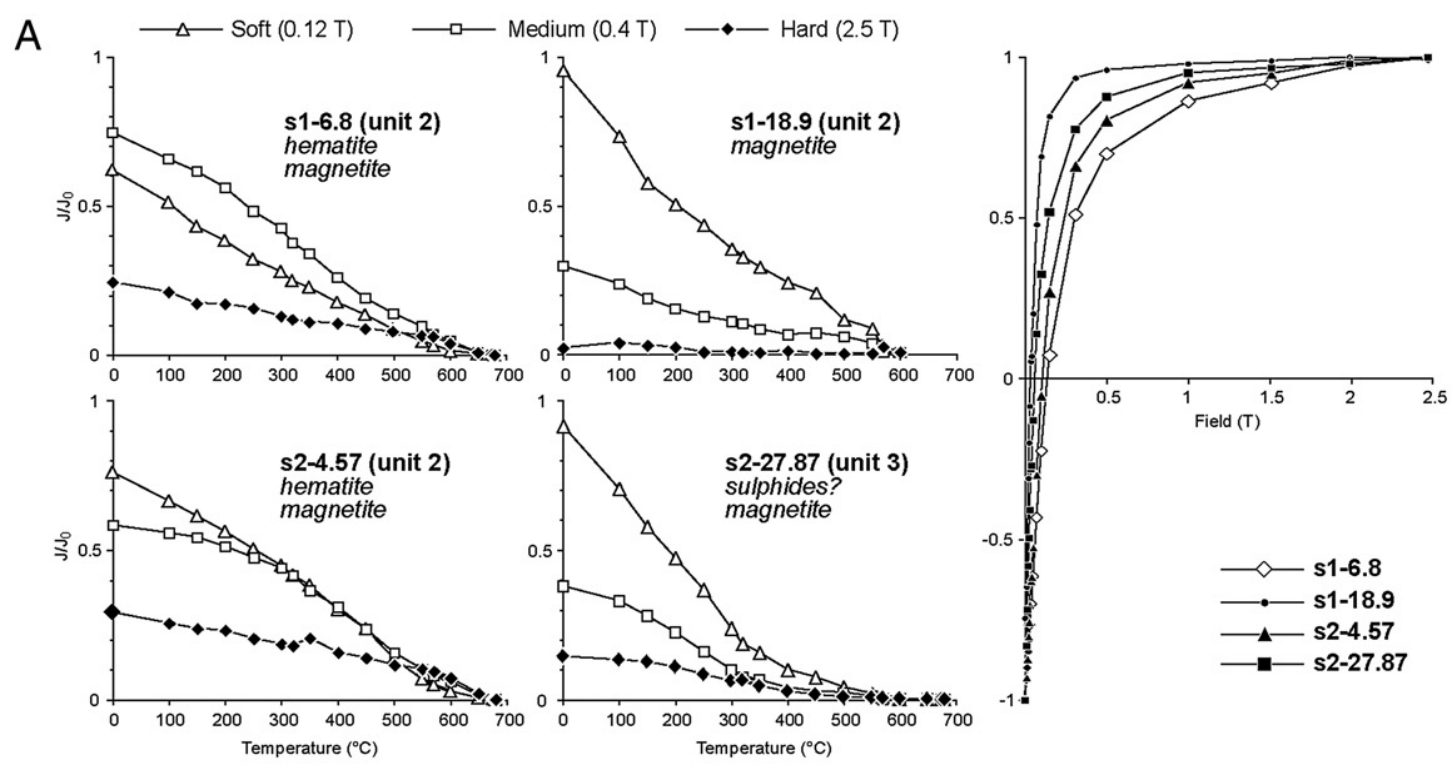

B Y,Up
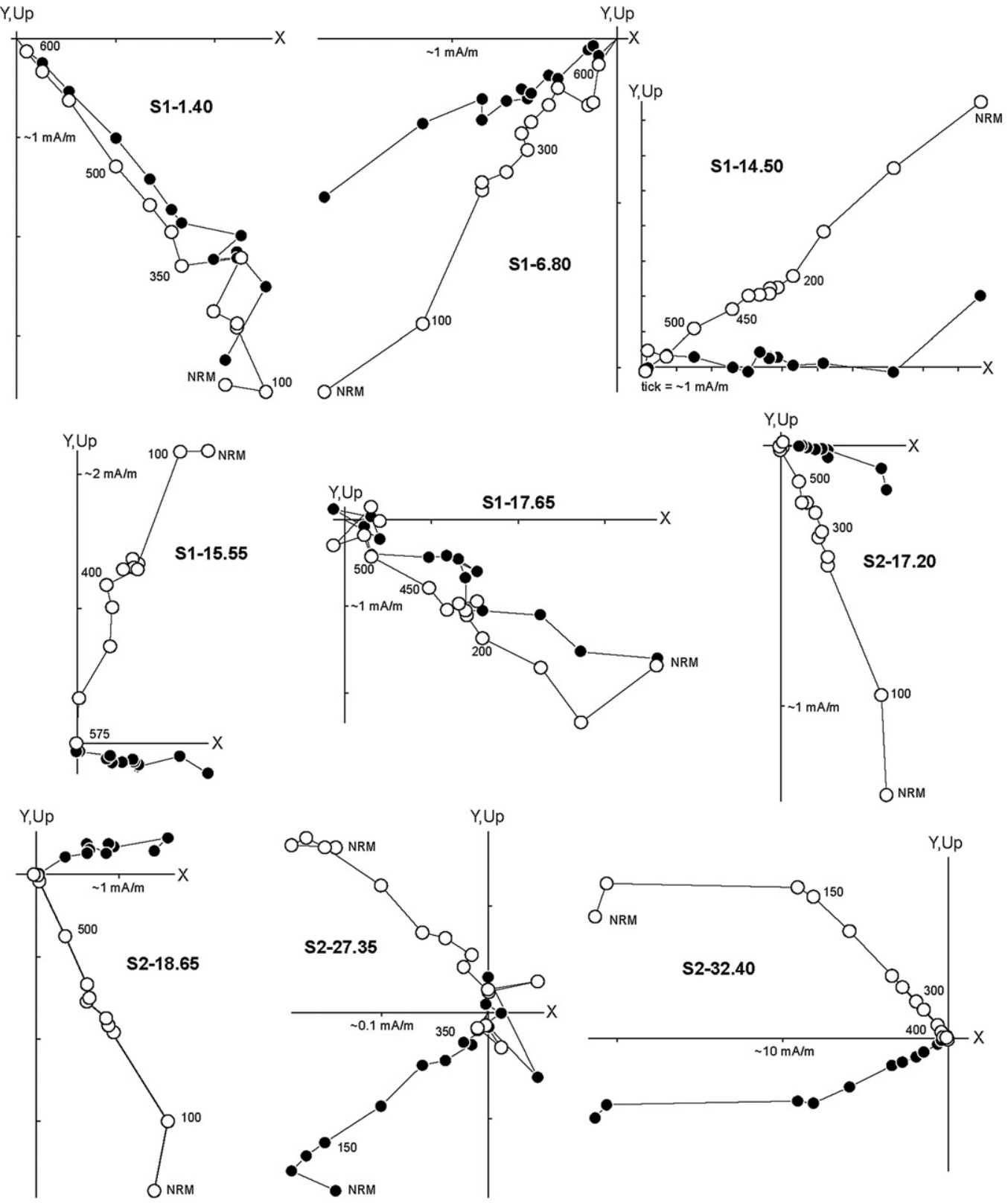
15.55; Fig. 8B) with up-pointing (negative) ChRM inclinations, whereas at Fontana Ranuccio 2, there are positive and many more negative ChRM inclinations (e.g., samples s2-17.20, s2-18.65, s2-27.35, and s2-32.40; Fig. 8B).

We applied the inclination-only statistics of McFadden and Reid (1982) to all Fontana Ranuccio 1 and Fontana Ranuccio 2 ChRM components and obtained an overall mean ChRM inclination of $51.5^{\circ} \pm 5.9^{\circ}(N=30 ; k=20)$, which is very similar to that at Ceprano but again somewhat shallower than the expected GAD inclination of $\sim 60^{\circ}$ due most probably to inclination shallowing in sediments (e.g., Tauxe, 2005).

Fontana Ranuccio 1 displays dominant positive ChRM inclinations through units $1-2$, interrupted only by the two samples with negative ChRM inclinations that define a single thin interval at $\sim 14.50-15.55 \mathrm{~m}$ within unit 2 immediately above a no-recovery interval (Fig. 6E, upper panel). At Fontana Ranuccio 2, an upper interval of positive ChRM inclinations encompassing alluvial unit 2 and the top of lacustrine unit 3 overlies a lower $\sim 11$ m-thick interval of consistent negative ChRM inclinations within the remaining part of unit 3 (Fig. 6E, lower panel).

The Fontana Ranuccio magnetostratigraphies placed in a topographic and geologic context (Fig. 5) show that the interval of predominantly positive ChRM inclination found at Fontana Ranuccio 1 persists laterally to Fontana Ranuccio 2 where it extends downsection for an additional $\sim 10 \mathrm{~m}$ and is underlain by a continuous interval of exclusive negative ChRM inclinations down to the core bottom. We interpret the positive ChRM inclinations recorded in both cores as representing a normal geomagnetic polarity, and the negative ChRM inclinations found in the lower part of Fontana Ranuccio 2 as representing an older interval of reverse geomagnetic polarity. However, Fontana Ranuccio 2 fails to reproduce the thin interval defined by two samples with negative ChRM inclinations observed within unit 2 at Fontana Ranuccio 1, which might represent a reverse polarity excursion of the geomagnetic field or, more likely, reflect local core disturbance during drilling as testified by the lack of recovery of sediments immediately below the interval itself coupled with the observation that this interval has not been observed in seemingly correlative levels at Fontana Ranuccio 2 (Fig. 5).

The regional context, the core lithostratigraphy, and the available $\mathrm{K}-\mathrm{Ar}$ chronologic constraints allow us to refer the upper normal polarity magnetozone to the Brunhes Chron ( $\mathrm{C} 1 \mathrm{n})$ and the lower reverse polarity magnetozone to the Matuyama Chron (C1r).

\section{Age models}

We developed age models for the Ceprano and Fontana Ranuccio cores by taking into account the available $\mathrm{K}-\mathrm{Ar}$ age constraints on lacustrine sedimentation. The Ceprano lithostratigraphy and the paleomagnetic (Brunhes) age constraints are broadly consistent with the stratigraphy of the Liri lacustrine sequence of the Latina Valley (Devoto, 1965; Fig. 1), constrained by $\mathrm{K}-\mathrm{Ar}$ ages between $0.354 \pm$ $0.007 \mathrm{Ma}$ and $0.583 \pm 0.010 \mathrm{Ma}$ (Carrara et al., 1995). To refine our Ceprano age model, we use the Lisiecki and Raymo (2005) $\delta^{18} O$ isotope curve and assume that lacustrine sedimentation (unit 2) took place essentially during an interglacial interval based on preliminary palynological data from the Ceprano 1 core (Margari et al., 2008). The underlying alluvial fan unit 3 is tentatively interpreted as deposited during a more arid glacial interval based on the systematic concurrence observed elsewhere, e.g. in the central Apennines (Nesci et al., 2002) or in several cores from northern Italy (Muttoni et al., 2003, 2007), between enhanced aridity during Pleistocene glacial intervals and the progradation of high-energy fluvial systems (e.g., alluvial fans) onto lower energy alluvial plains. Among the viable age model options, we consider the interglacial lacustrine sedimentation of unit 2 as most probably pertaining to MIS 13 although the available chronologic constraints do not preclude an attribution of unit 2 to either MIS 15 or MIS 11 (Fig. 9).

Our preferred age model yields an average sediment accumulation rate for lacustrine deposition of unit 2 on the order of $30 \mathrm{~cm} / \mathrm{ky}$. Simple linear extrapolation of this accumulation rate suggests that the age of the level that yielded the hominin cranium is $\sim 0.45$ Ma but more conservatively (i.e., taking into account the uncertainties illustrated above) between $\sim 0.35$ and $\sim 0.5 \mathrm{Ma}$ (Fig. 9). Our age model is a maximum age range for the hominin layer because it does not take into account the possible (albeit unrecognized) presence of major unconformities within marshy-fluvial unit 1 at Ceprano. In any case, a mean age of $\sim 0.45 \mathrm{Ma}$ for the layer containing the hominin cranium at Ceprano is indirectly supported by the $\mathrm{K}-\mathrm{Ar}$ age of $\sim 0.45 \mathrm{Ma}$ from the archaeological layer at Fontana Ranuccio (see also below), with the reasoning that both sites could plausibly represent the same Middle Pleistocene frequentation or occupation phase of the Latina Valley.

At Fontana Ranuccio, the correlation framework developed by tracing laterally the top and base of pyroclastic unit 1 (which changes elevation and thickness from Fontana Ranuccio 1 to Fontana Ranuccio 2 probably due to emplacement on a paleo-morphology; Fig. 5), coupled with the associated $\mathrm{K}-\mathrm{Ar}$ age of $0.487 \mathrm{Ma}$ (top of pyroclastics) and $0.528 \mathrm{Ma}$ (base of pyroclastics) (Biddittu et al., 1979), indicates that the upper normal polarity interval found in both cores is ascribable to the Brunhes Chron (C1n). The underlying reverse polarity interval found within lacustrine unit 3 at Fontana Ranuccio 2 is thus most consistent with the Matuyama Chron (C1r), with the Brunhes-Matuyama boundary $(0.78 \mathrm{Ma})$ placed at $\sim 22 \mathrm{~m}$ from the core top (Fig. 10). The Fontana Ranuccio archaeological layer (not drilled), found within weathered volcanic and volcanoclastic deposits resting above the pyroclastic unit 1 , should fall stratigraphically above the top of Fontana Ranuccio 1, well within the Brunhes Chron and consistent with a reported $\mathrm{K}-\mathrm{Ar}$ age of $0.458 \pm 0.006 \mathrm{Ma}$ (Biddittu et al., 1979; Segre and Ascenzi, 1984) (Fig. 10; see also Fig. 5). The tentative age model developed for Fontana Ranuccio by taking into account the available $\mathrm{K}-\mathrm{Ar}$ age constraints and the age of the Brunhes-Matuyama boundary indicates an average sediment accumulation rate for alluvial unit 2 and lacustrine unit 3 of $\sim 10 \mathrm{~cm} / \mathrm{ky}$ (Fig. 10). According to our age model, lacustrine unit 3 could have been deposited during interglacial MIS 19 within which the BrunhesMatuyama boundary is known to occur (Shackleton and Opdyke, 1976).

\section{Discussion and conclusions}

The Brunhes-Matuyama boundary was not encountered at Ceprano down to $45 \mathrm{~m}$ below the level that yielded the hominin cranium (Figs. 2 and 9). Hence, data from Ceprano do not support an age of the hominin cranium older than (or spanning) the BrunhesMatuyama boundary $(0.78 \mathrm{Ma})$ as has been previously suggested (Manzi, 2004 and references therein). The Ceprano lithostratigraphy and the paleomagnetic age constraints are broadly consistent with the stratigraphy of the Liri lacustrine sequence of the Latina Valley, constrained by $\mathrm{K}-\mathrm{Ar}$ ages between 0.354 and $0.583 \mathrm{Ma}$ (Carrara et al., 1995). In particular, the age model of sedimentation that we developed at Ceprano 1 indicates an age for the level that yielded

Fig. 8. (A) Rock-magnetic analyses on Fontana Ranuccio 1 (s1) and Fontana Ranuccio 2 (s2) samples using isothermal remanent magnetization (IRM) backfield acquisition curves (up to $2.5 \mathrm{~T}$ ) and thermal decay of a three component IRM (Lowrie, 1990) acquired along samples perpendicular axes in $2.5 \mathrm{~T}$ (high), $0.4 \mathrm{~T}$ (medium), and 0.12 T (low) fields. (B) Examples of Zijderveld (1967) demagnetization diagrams of Fontana Ranuccio 1 (s1) and Fontana Ranuccio 2 (s2) samples. Open (closed) symbols are projections onto the vertical (horizontal) plane. Horizontal projections have arbitrary azimuths, as cores were not oriented with respect to the geographic north. Samples are identified by the core code (s1, s2) and stratigraphic depth in meters from the top. 


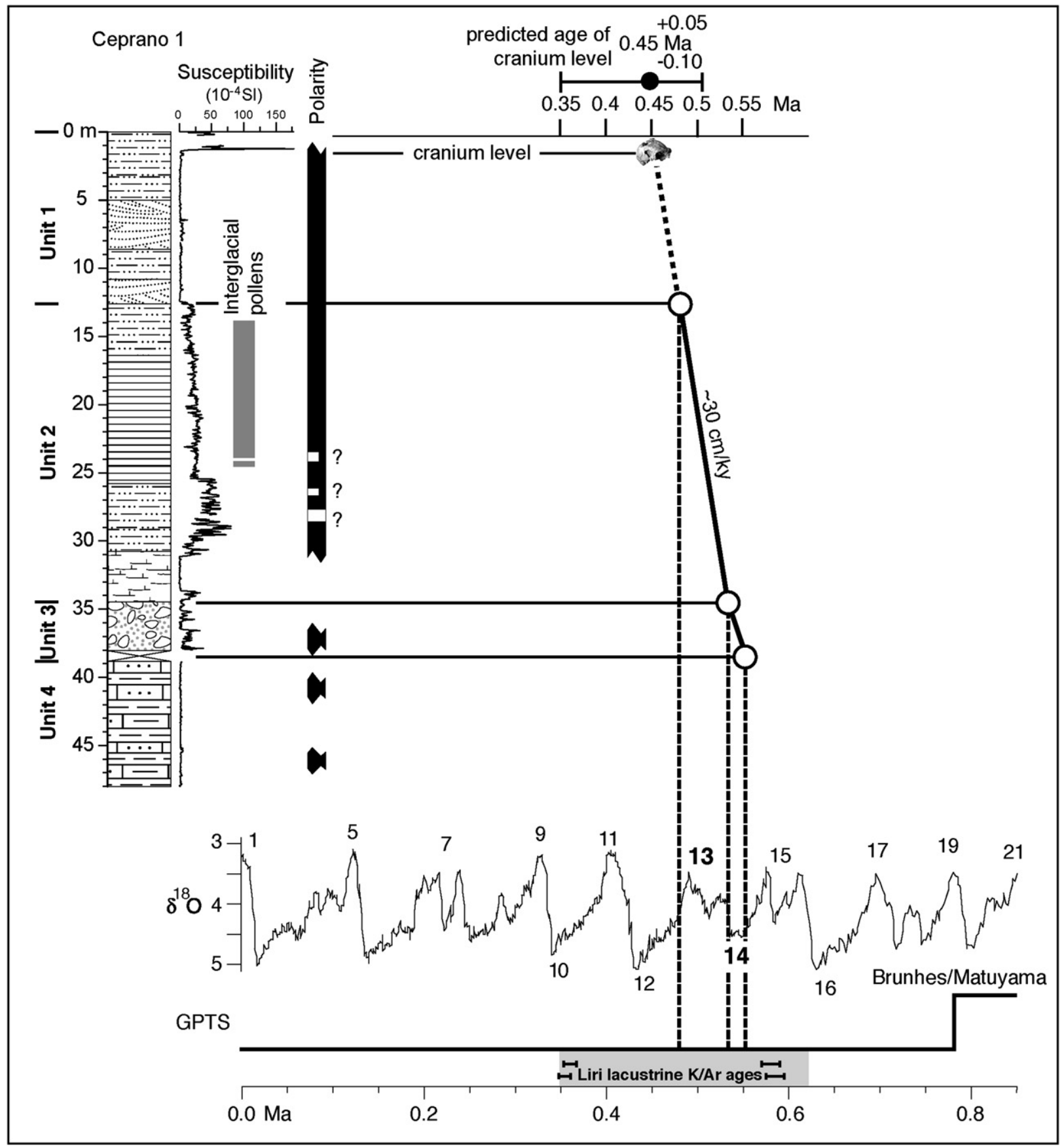

Fig. 9. Age model of sedimentation for the Ceprano 1 core developed by taking into account the available K-Ar age constraints on the Liri lacustrine sequences (Carrara et al., 1995) and the Lisiecki and Raymo (2005) $\delta^{18} \mathrm{O}$ isotope curve assuming that lacustrine sedimentation (unit 2) took place essentially during an interglacial interval, whereas alluvial fan deposition (unit 3) possibly during an arid glacial interval. In our preferred age model, lacustrine sedimentation of unit 2 corresponds to MIS 13 and alluvial fan deposition of unit 3 to MIS 14, although the available chronologic constraints do not preclude an attribution of unit 2 also to MIS 15 or MIS 11 . Simple linear extrapolation of this age model of sedimentation and associated uncertainties suggests an age of the stratigraphic level associated with the hominin cranium of $\sim 0.45(+0.05,-0.10)$ Ma.

the hominin cranium of $\sim 0.45(+0.05,-0.10)$ Ma (Fig. 9). On the other hand, we did find evidence for the Brunhes-Matuyama boundary at Fontana Ranuccio but it occurs $\sim 40 \mathrm{~m}$ below the level containing hominin teeth and the Acheulean industry dated by K-Ar to $\sim 0.46 \mathrm{Ma}$ (Biddittu et al., 1979; Segre and Ascenzi, 1984) (Figs. 5 and 10). The hominin levels at Ceprano and Fontana Ranuccio, both comprised well within the Brunhes normal polarity chron, may thus be similar in age at $\sim 0.45$ Ma.

We regard the hypothesis that the Ceprano cranium was reworked from much older deposits that are no longer extant (Ascenzi et al., 1996) as based on insufficient or indirect observations (examples of reworking from levels either above or below the hominin layer; highly fossilized nature of the skull, simply tagged as "incompatible" with the type of hosting sediment) that require validation by means of a comprehensive taphonomic study on the cranium as well as on the sediments it was originally encrusted with. In the absence of stringent evidence of reworking from much older sediments, we believe that the best estimate of the age of the cranium should be that of the stratigraphic level closest to where it was discovered $[\sim 0.45(+0.05$, $-0.10) \mathrm{Ma}$ ], which is about 300,000 years younger than the age close to the Brunhes-Matuyama boundary $(0.78 \mathrm{Ma})$ that has been conventionally assigned to the Ceprano hominin (e.g., Ascenzi et al., 1996, 2000; Antón, 2003; Manzi, 2004; Dennell, 2008) based on what we regard as indirect and flawed chronostratigraphic analyses. 


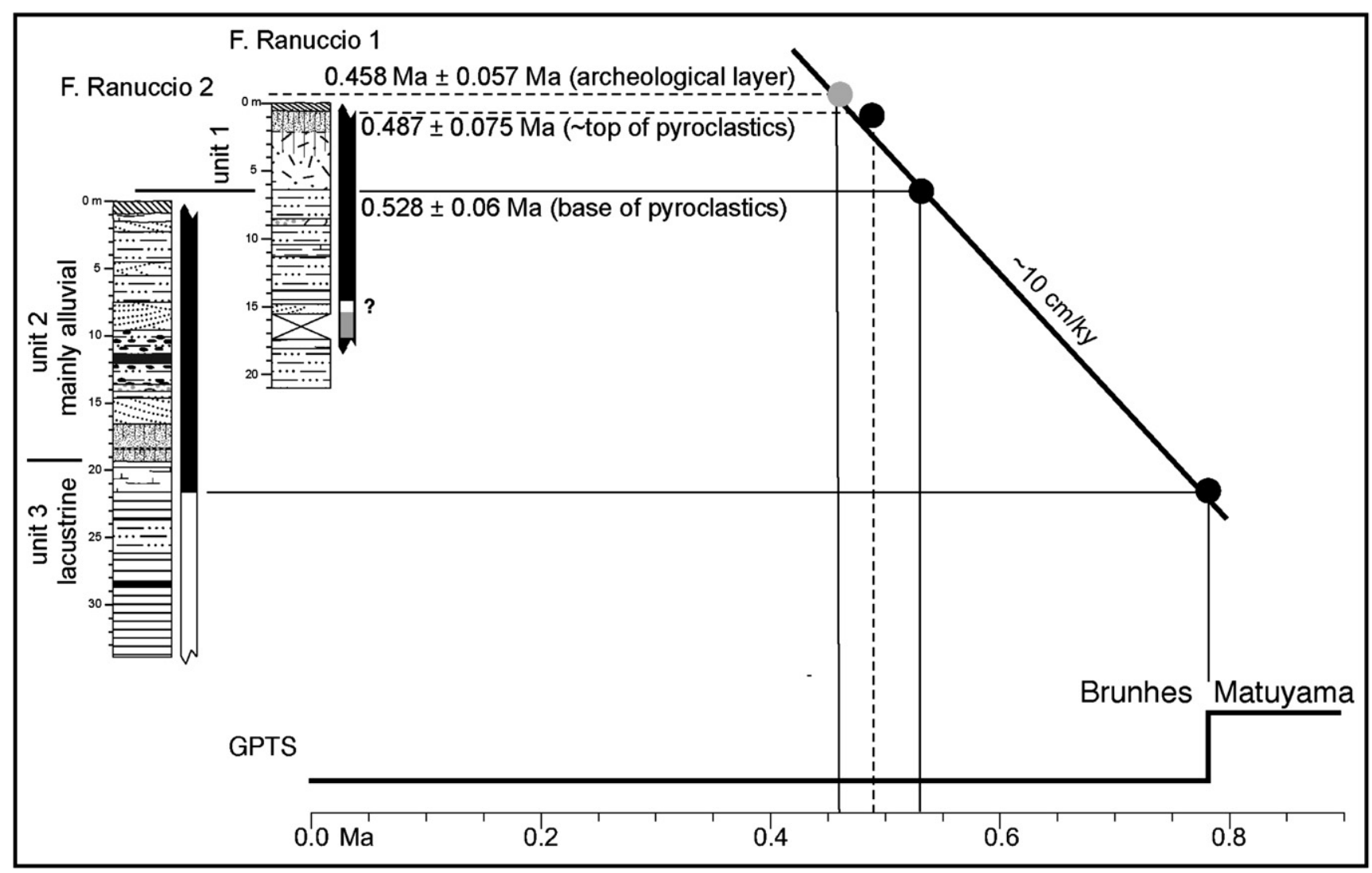

Fig. 10. Age model of sedimentation for the Fontana Ranuccio cores obtained by taking into account the available K-Ar age data from the archaeological level, located stratigraphically above the top of Fontana Ranuccio 1, from the base and top of pyroclastic unit 1 (Biddittu et al., 1979), as well as the age of the Brunhes-Matuyama boundary. The average sediment accumulation rate for alluvial unit 2 and lacustrine unit 3 is in the order of $\sim 10 \mathrm{~cm} / \mathrm{ky}$.

Other localities in Italy yielded evidence of early hominin frequentation-occupation in the Middle Pleistocene, albeit their chronologies are often not well documented (Villa, 2001). Notable exceptions are the previously mentioned hominin footsteps found in the Roccamonfina volcanic ash dated by ${ }^{40} \mathrm{Ar} /{ }^{39} \mathrm{Ar}$ on single leucite crystals to $0.345 \pm 0.006 \mathrm{Ma}$ (Scaillet et al., 2008), and Isernia la Pineta in central Italy where layer 3a with lithic tools is overlain by tuffs rich in pyroxenes and sanidines that yielded ${ }^{40} \mathrm{Ar} /{ }^{39} \mathrm{Ar}$ ages of $0.610 \pm 0.01$ and $0.606 \pm 0.002 \mathrm{Ma}$ (Coltorti et al., 2005). Sites in Italy potentially older than the Brunhes-Matuyama boundary $(0.78 \mathrm{Ma})$ are Cà Belvedere (Monte Poggiolo) in northern Italy (Peretto et al., 1998; Peretto, 2006) and Pirro Nord in southern Italy (Arzarello et al., 2007). Cà Belvedere was dated to 1 Ma based on an average electron spin resonance (ESR) age (Peretto et al., 1998; see also Villa, 2001 and Bahain et al., 2007) and on the inference that the original magnetization of the sediments is of reverse polarity (Gagnepain et al., 1992). Pirro Nord was dated to $\sim 1.7-1.3 \mathrm{Ma}$ using exclusively mammal biostratigraphy (Arzarello et al., 2007) that needs better calibration, for example, the mammal assemblage already does not seem to preclude an upper age limit for the site of $\sim 0.87 \mathrm{Ma}$ (Muttoni et al., 2007). Well-documented reverse polarity magnetizations attributed to the late Matuyama Chron ( $>0.78 \mathrm{Ma}$ ) have, however, been found in association with lithic artifacts and/or hominin remains elsewhere in southern Europe, a notable example being level TE9 at Sima del Elefante (Atapuerca, Spain) (Parés et al., 2006; Carbonell et al., 2008). These older ages recorded convincingly at Atapuerca indicate that the Mediterranean region, and especially Spain, saw a frequentationoccupation starting around the end of the Early Pleistocene (late Matuyama Chron) that was earlier than indicated by a shorter chronology of frequentation-occupation starting at $\sim 0.5 \mathrm{Ma}$, which characterized Europe north of the Alps and the Pyrenees (Dennell and Roebroeks, 1996; Roebroeks, 2001; Antón, 2003).
The Ceprano cranium, found in sediments dated to $\sim 0.45(+0.05$, -0.10) Ma, was temporally associated with a later frequentationoccupation and did not belong to one the earliest southern Europeans as has often been reported in the literature (e.g., Ascenzi et al., 1996; Antón, 2003; Manzi, 2004; Dennell, 2008). The revised age of the Ceprano cranium coupled with virtually the same age of the Fontana Ranuccio site testifies to the presence of hominins in peninsular Italy broadly during glacial MIS 12 ( 0.43-0.45 Ma). Speculatively, the MIS 12 climate deterioration may have triggered a migration pulse of hominins to more habitable southern European refugia, for example, Italy through a 'Venice corridor' in the northern Adriatic. In fact, the Venetian-Friulian Plain emerged for the first time no earlier than during the low-stand of MIS 12 as revealed by data from the Venice core (Kent et al., 2002) and the Azzano X core (Zanferrari et al., 2008), and this is about the inferred age of the hominins of Ceprano and Fontana Ranuccio in central Italy.

\section{Acknowledgements}

Helpful comments by Roberto Lanza, Mauro Coltorti, and an anonymous reviewer greatly improved this manuscript. We thank A.G. Segre for providing access to the Fontana Ranuccio cores. Drilling at Ceprano 1 has been financed by the Istituto per la Dinamica dei Processi Ambientali (IDPA) of the Consiglio Nazionale delle Ricerche (CNR) (P.M. Rossi), whereas drilling at Ceprano 2, Fontana Ranuccio 1, and Fontana Ranuccio 2 has been financed by the Istituto Italiano di Paleontologia Umana (Rome). The preliminary description of the Ceprano cores lithostratigraphy was performed in collaboration with S. Milli. We thank B. Narcisi (ENEA) for providing information on the $\mathrm{K}-\mathrm{Ar}$ age determinations from the Liri lacustrine sequence of Carrara et al. (1995). A.G. Segre, E. Segre Naldini, F. Parenti, M. Saroli, D. Magri, I. Biddittu, F. Tremolada, L. Vezzoli, M.B. Cita, M. Cremaschi, and B. 
Saracino are thanked for stimulating discussions. F. Parenti provided the topographic surveys of the Ceprano and Fontana Ranuccio sites. This is Lamont-Doherty contribution \#7281.

\section{Appendix A. Supplementary data}

Supplementary data associated with this article can be found, in the online version, at 10.1016/j.epsl.2009.06.032.

\section{References}

Alberti, A.U., Bergomi, C., Catenacci, V., Centamore, E., Cestari, G., Chiocchini, M. Chiocchini, U., Manganelli, V., Molinari-Paganelli, V., Panseri-Crescenzi, C., Salvati, L., Tilia-Zuccari, A., 1975. Note Illustrative del Foglio 389 Anagni. Servizio Geologico d'Italia, Litografia Artistica Cartografica, Firenze. 42 p.

Antón, S.C., 2003. Natural history of Homo erectus. Yearb. Phys. Anthropol. 46, 126-170.

Arzarello, M., Marcolini, F., Pavia, G., Pavia, M., Petronio, C., Petrucci, M., Rook, L Sardella, R., 2007. Evidence of earliest human occurrence in Europe: the site of Pirro Nord (Southern Italy). Naturwissenschaften 94, 107-112.

Ascenzi, A. Biddittu, I. Cassoli, P.F., Segre, A.G., Segre Naldini, E., 1996. A calvarium of late Homo erectus from Ceprano, Italy. J. Hum. Evol. 31, 409-423.

Ascenzi, A., Segre, A.G., 1997. Discovery of a Homo erectus calvarium at Ceprano, Centra Italy. Anthropologie 35, 241-246.

Ascenzi, A., Mallegni, F., Manzi, G., Segre, A.G., Segre Naldini, E., 2000. A re-appraisal of Ceprano calvaria affinities with Homo erectus, after the new reconstruction. J. Hum. Evol. 39, 443-450.

Bahain, J.-J., Falguères, C., Voinchet, P., Duval, M., Dolo, J.-M., Despriée, J., Garcia, T., Tissoux, H., 2007. Electron spin resonance (ESR) dating of some European late lowe Pleistocene sites. Quaternaire 18 (2), 175-186.

Berggren, W.A. Hilgen, FJ. Langereis, C.G. Kent, D.V Obradovich, J.D., Raffi, I., Raymo, M.E., Shackleton, N.J., 1995. Late Neogene chronology: new perspectives in highresolution stratigraphy. Geol. Soc. Amer. Bull. 107, 1272-1287.

Biddittu, I., Cassoli, P.F., Radicati Di Brozolo, F., Segre, A.G., Segre Naldini, E., Villa, I., 1979 Anagni, a K-Ar dated Lower and Middle Pleistocene Site, Central Italy: preliminary report. Quaternaria 21, 53-71.

Bruner, E., Manzi, G., 2005. CT-based description and phyletic evaluation of the archaic human calvarium from Ceprano, Italy. Anat. Rec. 285A, 643-658.

Bruner, E., Manzi, G., 2007. Landmark-based shape analysis of the archaic Homo calvarium from Ceprano (Italy). Am. J. Phys. Anthropol. 132, 355-366.

Carbonell, E., et al., 2008. The first hominin of Europe. Nature 452, 465-470. doi:10.1038 nature06815.

Carrara, C., Frezzotti, M., Giraudi, C., 1995. Stratigrafia plio-quaternaria. In: Carrara, C. (Ed.), Lazio Meridionale, Sintesi delle ricerche geologiche multidisciplinari. ENEA, pp. 62-85.

Clarke, R.J., 2000. A corrected reconstruction and interpretation of the Homo erectus skull from Ceprano, Italy. J. Hum. Evol. 39, 433-442.

Coltorti, M., Feraud, G., Marzoli, A., Peretto, C., Ton-That, T., Voinchet, P., Bahain, J.-J. Minelli, A., Thun Hohenstein, U., 2005. New 40Ar/39Ar, stratigraphic and palaeoclimatic data on the Isernia La Pineta Lower Palaeolithic site, Molise, Italy. Quat. Int. 131, 11-22.

Dennell, R.W., 2008. Human migration and occupation of Eurasia. Episodes 31, 207-210.

Dennell, R.W., Roebroeks, W., 1996. The earliest colonization of Europe: the shor chronology revisited. Antiquity 70, 535-542.

De Rita, D., Giordano, G., 1996. Volcanological and structural evolution of Roccamonfina volcano (Italy): origin of the summit calder. In: McGuire, W.J., Jones, A.P., Neuberg, J. (Eds.), Volcano Instability on the Earth and Other Planets, 110. Geological Society Special Publication, pp. 209-224.

Devoto, G., 1965. Lacustrine Pleistocene in the lower Liri Valley (southern Latium). Geol. Rom. 4, 291-368.

Fornaseri, M., 1985. Geochronology of volcanic rocks from Latium, Italy. R. Soc. Ital. Mineral. Petrol. 40, 74-106.

Gagnepain, J., Hedley, I., Bahain, J.-J., Wagner, J.J., 1992. Etude magnetostratigraphique du site de Ca' Belvedere di Monte Poggiolo (Forli, Italie) et de son contexte stratigraphique. Premiers resultats. In: Peretto, C. (Ed.), I primi abitanti della valle Padana: Monte Poggiolo nel quadro delle conoscenze europee. Jaca Book, Milan, pp. 319-329.

Galadini, F., Messina, P., 2004. Early-Middle Pleistocene eastward migration of the Abruzzi Apennine (central Italy) extensional domain. J. Geodyn. 37, 57-81.

Giannetti, B., 2001. Origin of the calderas and evolution of Roccamonfina volcano (Roman Region, Italy). J. Volcanol. Geotherm. Res. 106, 301-319.

Giordano, G., De Benedetti, A.A., Diana, A., Diano, G., Gaudioso, F., Marasco, F., Miceli, M., Mollo, S., Cas, R.A.F., Funiciello, R., 2006. The Colli Albani mafic caldera (Roma, Italy): stratigraphy, structure and petrology. J. Volcanol. Geotherm. Res. 155, 49-80.
Hrouda, F., 2002. The use of the anisotropy of magnetic remanence in the resolution of the anisotropy of magnetic susceptibility into its ferromagnetic and paramagnetic components. Tectonophysics 347, 269-281.

Kent, D.V., Rio, D., Massari, F., Kukla, G., Lanci, L., 2002. Emergence of Venice during the Pleistocene. Quat. Sci. Rev. 21, 1719-1727.

Kirschvink, J.L., 1980. The least-squares line and plane and the analysis of palaeomagnetic data. Geophys. J. R. Astron. Soc. 62, 699-718

Lisiecki, L.E., Raymo, M.E., 2005. A Pliocene-Pleistocene stack of 57 globally distributed benthic D180 records. Paleoceanography 20, PA1003. doi:10.1029/2004PA001071.

Lowrie, W., 1990. Identification of ferromagnetic minerals in a rock by coercivity and unblocking temperature properties. Geophys. Res. Lett. 17, 159-162.

Mallegni, F., Carnieri, C., Bisconti, M., Tartarelli, G., Ricci, S., Biddittu, I., Segre, A., 2003. Homo cepranensis sp. nov. and the evolution of African-European Middle Pleistocene hominids. Comptes Rendus Palevol 2,153-154.

Manzi, G., Mallegni, F., Ascenzi, A., 2001. A cranium for the earliest Europeans: phylogenetic position of the hominid from Ceprano, Italy. Proc. Natl. Acad. Sci. 98 , 10011-10016.

Manzi, G., 2004. Human evolution at the Matuyama-Brunhes boundary. Evol. Anthropol. 13, 11-24.

Margari, V., Magri, D., Manzi, G., Tzedakis, C., 2008. Middle Pleistocene interglacial vegetation in southern Europe: a new pollen record from the Ceprano basin, Central Italy. 12th International Palynological Congress IPC-XII 2008, Bonn.

McFadden, P.L., Reid, A.B., 1982. Analysis of palaeomagnetic inclination data. Geophys. J. Royal Astron. Soc. 69, 307-319.

Mietto, P., Avanzini, M., Rolandi, G., 2003. Human footprints in Pleistocene volcanic ash Nature 422,133

Muttoni, G., Carcano, C., Garzanti, E., Ghielmi, M., Piccin, A., Pini, R., Rogledi, S., Sciunnach, D., 2003. Onset of major Pleistocene glaciations in the Alps. Geology 31 989-992.

Muttoni, G., Ravazzi, C., Breda, M., Laj, C., Kissel, C., Mazaud, A., Pini, R., Garzanti, E., 2007. Magnetostratigraphy of the Leffe lacustrine succession (Southern Alps, Italy): evidence for an intensification of glacial activity in the Alps at Marine Isotope Stage 22 (0.87 Ma). Quat. Res. 67, 161-173.

Nesci, O., Savelli, D., Tramontana, M., Veneri, F., De Donatis, M., Mazzoli, S., 2002. The evolution of alluvial fans in the Umbria-Marche-Romagna Apennines (Italy) Bollettino della Societa Geologica Italiana, Special Volume 1, pp. 915-922.

Parés, J.M., Pérez-Gonzalez, A., Rosas, A., Benito, A., Bermudez de Castro, J.M., Carbonell, E., Huguet, R., 2006. Matuyama-age lithic tools from the Sima del Elefante site, Atapuerca (northern Spain). J. Hum. Evol. 50, 163-169.

Peccerillo, A., 2005. Plio-Quaternary Volcanism in Italy. Petrology, Geochemistry, Geodynamics. Springer. 365 pp.

Peretto, C., Amore, F.O., Antoniazzi, A., Antoniazzi, A., Bahain, J.-J., Cattani, L., Cavallini, E., Esposito, P., Falguères, C., Gagnepain, J., Hedley, I., Laurent, M., Lebreton, V., Longo, L., Milliken, S., Monegatti, P., Ollé, A., Pugliese, N., Renault-Miskovsky, J., Sozzi, M., Ungaro, S., Vannucci, S., Verges, J.-M., Wagner, J.-J., Yokoyama, Y., 1998. L'industrie lithique de Ca' Belvedere di Monte Poggiolo: stratigraphie, matiere premiere, typologie, remontages et traces d'utilisation. L'Anthropologie 102 (4), 343-365.

Peretto, C., 2006. The first peopling of southern Europe: the Italian case. C. R. Palevol. 5 , 283-290.

Roebroeks, W., 2001. Hominid behaviour and the earliest occupation of Europe: an exploration. J. Hum. Evol. 41, 437-461.

Rouchon, V., Gillot, P.Y., Quidelleur, X., Chiesa, S., Floris, B., 2008. Temporal evolution of the Roccamonfina volcanic complex (Pleistocene), Central Italy. J. Volcanol. Geotherm. Res. 177, 500-514.

Scaillet, S., Vita-Scaillet, G., Guillou, H., 2008. Oldest human footprints dated by $\mathrm{Ar} / \mathrm{Ar}$ Earth Planet. Sci. Lett. 275, 320-325.

Segre, A.G., Ascenzi, A., 1984. Fontana Ranuccio: Italy's earliest Middle Pleistocene hominid site. Curr. Anthropol. 25, 230-233.

Segre, A.G., 2004. Guida ai giacimenti pleistocenici e villafranchiani del Lazio meridionale. Quat. Nova 7, 205-232.

Segre Naldini, E., Muttoni, G., Parenti, F., Scardia, G., Segre, A.G., 2009. Nouvelles recherches dans le bassin Plio-Pléistocène de Anagni (Latium méridional, Italie). L'Anthropologie 113, 66-77.

Shackleton, N.J., Opdyke, N.D., 1976. Oxygen-isotope and paleomagnetic stratigraphy of Pacific core V28-239: Late Pliocene to latest Pleistocene. Geol. Soc. Am. Memoir $145,449-464$

Steiger, R.H., Jager, E., 1977. Subcommission on geochronology: convention on the use of decay constants in geo- and cosmochronology. Earth Planet. Sci. Lett. 36, 359-362.

Tauxe, L., 2005. Inclination flattening and the geocentric axial dipole hypothesis. Earth Planet. Sci. Lett. 233, 247-261.

Villa, P., 2001. Early Italy and the colonization of Western Europe. Quat. Int. 75, 113-130.

Zanferrari, A., Avigliano, R., Fontana, A., Paiero, G., 2008. Note Illustrative del Foglio 86 San Vito al Tagliamento. Servizio Geologico, Regione Friuli Venezia Giulia, Graphic Linea, Udine. $190 \mathrm{p}$

Zijderveld, J.D.A., 1967. A.C. demagnetization of rocks - analysis of results. In: Collinson, D.W., Creer, K.M., Runcorn, S.K. (Eds.), Methods in Paleomagnetism. New York, Elsevier, pp. 254-286. 